\title{
The Paleoecological Record of 6 ka BP Climate in the Canadian Prairie Provinces
}

\section{Données paléoécologiques sur le climat des provinces des} Prairies à 6 ka BP

\section{Palaoökologische Belege über das Klima in den kanadischen Prärie-Provinzen um 6 ka v.u.Z.}

\author{
Robert E. Vance, Alwynne B. Beaudoin et Brian H. Luckman
}

Volume 49, numéro 1, 1995

La paléogéographie et la paléoécologie d’il y a 6000 ans BP au Canada Paleogeography and Paleoecology of 6000 yr BP in Canada

URI : https://id.erudit.org/iderudit/033031ar

DOI : https://doi.org/10.7202/033031ar

Aller au sommaire du numéro

\section{Éditeur(s)}

Les Presses de l'Université de Montréal

ISSN

0705-7199 (imprimé)

1492-143X (numérique)

Découvrir la revue

Citer cet article

Vance, R. E., Beaudoin, A. B. \& Luckman, B. H. (1995). The Paleoecological Record of 6 ka BP Climate in the Canadian Prairie Provinces. Géographie physique et Quaternaire, 49(1), 81-98. https://doi.org/10.7202/033031ar
Résumé de l'article

La synthèse des études paléoécologiques montrent qu'à 6 ka le maximum d'aridité, qui caractérisait l'Holocène inférieur, avait été atteint, mais le climat demeurait plus chaud et plus sec que maintenant dans toute la région. Les différentes limites des arbres étaient plus élevées qu'aujourd'hui et la superficie des glaciers alpins étaient plus petite, les niveaux lacustres étaient moins élevés dans la plus grande partie des plaines intérieures et les écozones des Prairies et de la forêt boréale s'étendaient plus au nord qu'aujourd'hui. Les feux de forêt étaient plus fréquents à 6 ka qu'actuellement, ce qui a favorisé la migration du pin gris (Pinus banksiana) vers l'ouest à travers la forêt boréale et accru la superficie de la prairie dans les zones de forêts boréale et alpine. Les essais faits dans le but de mesurer l'ampleur des différences de températures et de précipitations à $6 \mathrm{ka}$ ont donné des résultats variables, mais montrent que la température était de 0,5 à $1,5^{\circ} \mathrm{C}$ plus élevé que maintenant (avec une température estivale jusqu'à $3^{\circ} \mathrm{C}$ plus élevée) et les précipitations annuelles moyennes étaient de $65 \mathrm{~mm}$ inférieures (avec des précipitations estivales de 50 $\mathrm{mm}$ inférieures) à maintenant. La nature et le degré des changements laissent croire qu'une forte circulation atmosphérique zonale, semblable à celle des années 1930, mais plus nordique, existait à 6 ka.
Tous droits réservés ㄷ Les Presses de l'Université de Montréal, 1995

Ce document est protégé par la loi sur le droit d'auteur. L'utilisation des services d'Érudit (y compris la reproduction) est assujettie à sa politique d'utilisation que vous pouvez consulter en ligne.

https://apropos.erudit.org/fr/usagers/politique-dutilisation/ 


\section{THE PALEOECOLOGICAL RECORD OF 6 KA BP CLIMATE IN THE CANADIAN PRAIRIE PROVINCES*}

Robert E. VANCE, Alwynne B. BEAUDOIN and Brian H. LUCKMAN, respectively: Geological Survey of Canada, 3303$33^{\text {td }}$ St. NW, Calgary, Alberta T2L 2A7; Archaeological Survey, Provincial Museum of Alberta, 12845-102 ${ }^{\text {nd }}$ Ave., Edmonton, Alberta T5N 0M6; Department of Geography, University of Western Ontario, London, Ontario N6A 5C2.

\begin{abstract}
Synthesis of available paleoecological studies in the prairie provinces of Canada indicates that although the peak in postglacial aridity that characterized early Holocene climate of the western foothills and plains had passed, conditions remained warmer and drier than present throughout the region ca. 6000 yr BP. Compared to today, treeline elevations were higher and alpine glaciers were reduced in size in the Rocky Mountains, lake levels were lower over much of the Interior Plains, and the grassland and boreal forest ecozones extended north of their present positions. Forest fires were more prevalent ca. $6000 \mathrm{yr}$ BP than they are today, aiding westward migration of jack pine (Pinus banksiana) through the boreal forest and increasing the area occupied by grassland in boreal and montane forest regions. Attempts to quantify the magnitude of $6 \mathrm{ka}$ temperature and precipitation differences have produced variable results, but suggest that mean annual temperature was $0.5^{\circ} \mathrm{C}$ to $1.5^{\circ} \mathrm{C}$ higher than today (summer temperature may have been up to $3^{\circ} \mathrm{C}$ higher) and mean annual precipitation was reduced by $65 \mathrm{~mm}$ (or summer precipitation was reduced by $50 \mathrm{~mm}$ ), compared to present. The nature and scale of these changes suggests that a vigorous zonal atmospheric circulation pattern, similar to that of the 1930s but shifted northward, prevailed at $6 \mathrm{ka}$.
\end{abstract}

RÉSUMÉ Données paléoécologiques sur le climat des provinces des prairies à $6 \mathrm{ka}$. $B P$. La synthèse des études paléoécologiques montrent qu'à 6 ka le maximum d'aridité, qui caractérisait l'Holocène inférieur, avait été atteint, mais le climat demeurait plus chaud et plus sec que maintenant dans toute la région. Les différentes limites des arbres étaient plus élevées qu'aujourd'hui et la superficie des glaciers alpins étaient plus petite, les niveaux lacustres étaient moins élevés dans la plus grande partie des plaines intérieures et les écozones des prairies et de la forêt boréale s'étendaient plus au nord qu'aujourd'hui. Les feux de forêt étaient plus fréquents à 6 ka qu'actuellement, ce qui a favorisé la migration du pin gris (Pinus banksiana) vers l'ouest à travers la forêt boréale et accru la superficie de la prairie dans les zones de forêts boréale et alpine. Les essais faits dans le but de mesurer l'ampleur des différences de températures et de précipitations à 6 ka ont donné des résultats variables, mais montrent que la température était de 0,5 à $1,5^{\circ} \mathrm{C}$ plus élevé que maintenant (avec une température estivale jusqu'à $3^{\circ} \mathrm{C}$ plus élevée) et les précipitations annuelles moyennes étaient de $65 \mathrm{~mm}$ inférieures (avec des précipitations estivales de $50 \mathrm{~mm}$ inférieures) à maintenant. La nature et le degré des changements laissent croire qu'une forte circulation atmosphérique zonale, semblable à celle des années 1930, mais plus nordique, existait à $6 \mathrm{ka}$.
ZUSAMMENFASSUNG Palaoökologische Belege über das Klima in den kanadischen Prärie-Provinzen um 6 ka v.u.Z. Die Synthese der verfügbaren paläoökologischen Studien in den Prärie-Provinzen Kanadas zeigt, daß das Klima in der ganzen Region um etwa 6000 Jahre v.u.Z. wärmer und trockener als gegenwärtig blieb, wenn auch das Maximum an postglazialer Trockenheit, welches im frühen Holozän das Klima der westlichen Gebirgsausläufer und Ebenen charakterisierte, vorüber war. Verglichen mit heute waren die Baumgrenzen höher und die alpinen Gletscher in den Rocky Mountains kleiner, die Seehöhen waren niedriger im größten Teil der inneren Ebenen, und die Ökozonen von Grasland und nördlichem Wald erstreckten sich weiter nördlich als heute. Waldbrände traten um etwa 6000 v.u.Z. häufiger als gegenwärtig auf und haben so die Westwärtswanderung von Graukiefer (Pinus banksiana) durch den nördlichen Wald begünstigt und die Graslandflächen in den Gebieten des nördlichen und alpinen Waldes vergrößert. Versuche, den Umfang der Unterschiede in Temperatur und Niederschlägen um 6 ka zu bestimmen, ergaben wechselnde Ergebnissse, doch zeigen sie, daß die durchschnittliche jährliche Temperatur $0.5^{\circ}$ $\mathrm{C}$ bis $1.5^{\circ} \mathrm{C}$ höher als gegenwärtig war (die Sommertemperatur dürfte bis zu $3^{\circ} \mathrm{C}$ höher gewesen sein) und die durchschnittlichen jährlichen Niederschläge waren um $65 \mathrm{~mm}$ geringer (oder die Sommer-Niederschläge waren um $50 \mathrm{~mm}$ geringer) verglichen mit heute. Die Natur und der Grad dieser Wechsel lassen vermuten, daß eine kräftige zonale atmosphärische Strömung, ähnlich der von den 1930 iger Jahren aber nördlicher gelagert, um 6 ka vorherrschte.

\footnotetext{
Manuscrit reçu le 10 juin 1994; manuscrit révisé accepté le 7 novembre 1994

* Geological Survey of Canada Contribution No. 52193
} 


\section{INTRODUCTION}

Shifts in the position of regional vegetation belts and changes to regional surface hydrology are among the clearest indicators of past climate change. Over the last twentyfive years, an extensive network of paleoecological study sites focused on these topics has been developed in Manitoba, Saskatchewan, and Alberta; a network of sufficient scope to allow a preliminary assessment of paleoclimatic conditions across the Canadian Prairies. A number of paleoclimatic indices may be consulted to reconstruct climatic conditions ca. $6000 \mathrm{yr} \mathrm{BP}$, including several pollen stratigraphic studies from all ecological zones, investigation of high altitude glacier and treeline dynamics in the Rocky Mountains, as well as a number of diverse paleolimnological studies. The purpose of this synthesis is to describe, both qualitatively and quantitatively, how climatic conditions 6000 years ago differed from those of today. This period is of interest now because the 6 ka time slice has been chosen by the NATO sponsored Paleoclimate Model Intercomparison Project as one point for testing Global Climate Model output with the paleoecological record (Jetté, 1995).

Proxy indicators provide indirect evidence of past climate, but the signal may be muted or filtered by interaction with other environmental factors. As a result, it is rarely possible to use a single proxy data record directly for climatic reconstruction. Moreover, a specific proxy indicator may reflect different climatic parameters in differing areas or ecozones. To date, most research has focused on biotic proxy indicators, producing a wealth of paleoecological information from remains preserved in lake sediment, including indicators of terrestrial conditions (e.g., pollen) and limnological indicators (e.g., diatoms). Cases where several indicators have been studied at a single site are particularly valuable because they provide an opportunity to link the environmental history of the terrestrial and limnological systems.

Ritchie $(1976,1985,1987,1989)$ has summarized much of the existing pollen data in western Canada as part of a broad regional history of the major vegetation zones of Canada. Anderson et al. (1989) discussed paleoecological data (mainly pollen) pertinent to the Hypsithermal interval in western Canada (ca. 9000-4000 yr BP), and Ritchie and Harrison (1993) outlined Holocene vegetation and lake level dynamics in western Canada, again relying mainly on pollen data. Although providing valuable overviews, these surveys are neither comprehensive nor focus specifically on the $6 \mathrm{ka}$ interval. The main source of proxy data cited in this paper is also pollen, but these data are supplemented by information on glacier dynamics, macrofossil evidence of high altitude treeline dynamics, sedimentologic and biotic evidence of lake-level changes, and pedologic data related to past aeolian and alluvial activity, in an attempt to bring together as many published and unpublished sources of data pertinent to the $6 \mathrm{ka}$ interval as possible.

\section{SETTING}

The term 'prairie provinces' (Fig. 1) invokes an inapproriate image of vast tracts of an essentially feature- less landscape of gently undulating grassland. In fact, the three prairie provinces embody a great deal of geomorphic, climatic, and ecological variability. Large scale physiographic features, shaped by Cretaceous and Tertiary bedrock, form a series of prairie 'steps' across the southern half of the three provinces (Klassen, 1989). The easternmost step, the Manitoba Escarpment, separates the Manitoba Plain (ca. $250 \mathrm{~m}$ asl) from the Saskatchewan Plain (ca. 400-800 m asl) which, in turn, is separated from the Alberta Plain (ca. 800-1000 $\mathrm{m}$ asl) by the Missouri Coteau. The Alberta Plain grades into the eastern slope foothills of the Rocky Mountains which rise steeply to the continental divide at $\mathrm{ca}$. $3000 \mathrm{~m}$ asl) In the northwest, the Alberta Plateau (ca. 600$900 \mathrm{~m}$ asl) is dissected by the Peace River Lowland (ca. 300-600 m asl). The northeastern portion of the prairie provinces is part of the Precambrian Shield, whose surface expression consists of extensive poorly drained, low relief plains and plateaus dotted with numerous lakes and wetlands. This topography contrasts markedly with the southern prairies where low relief is interrupted by several prominent uplands (e.g., Turtle Mountain, Wood Mountain, and the Cypress Hills).

The prairie provinces are drained to the north by major tributaries of the Mackenzie system flowing to the Arctic Ocean, the Churchill and Saskatchewan-Nelson River systems draining east to Hudson Bay, and to the south by Mississippi tributaries flowing to the Gulf of Mexico. Many of these major river systems have their headwaters in the western Cordillera. Several rivers (e.g., the Bow and Saskatchewan) are glacier-fed and have cut deeply incised valleys across the Interior Plains. Thus the hydrological system integrates inputs from the Rocky Mountains and Interior Plains and responds to precipitation and glacier mass changes in the headwaters as well as changes in precipitation and evaporation on the prairie surface.

The size and physiographic diversity of the prairie provinces makes it impossible to specify climatic parameters for the entire region. However, broad scale features of western interior climate are dictated mainly by the interaction of Arctic and Pacific air masses (although summers in the southeast are influenced by warm, moist air masses originating in the Gulf of Mexico). During winter months, when the core of westerly atmospheric circulation typically migrates south of the Canadian border, incursions of Pacific air are infrequent and the area is often blanketed by cold, dry Arctic air. With the northward movement of the westerly core during spring and summer, Pacific air masses occupy the area more frequently, particularly in the south. This shift in air mass dominance produces pronounced seasonal extremes in temperature and precipitation. For the period 1930-1980, mean January temperatures in southern regions have been about $-10^{\circ} \mathrm{C}$ and mean July temperatures about $+20^{\circ} \mathrm{C}$, whereas in the north seasonal extremes vary between $-25^{\circ} \mathrm{C}$ and $+15^{\circ} \mathrm{C}$ (Longley, 1972; Atmospheric Environment Service, 1982). Mean annual precipitation for the same period is variable, with peak values registered in west central Alberta $(600 \mathrm{~mm})$ and south central Manitoba $(500 \mathrm{~mm})$, and a low of $300 \mathrm{~mm}$ recorded in southeastern Alberta and southwestern Saskatchewan. Measurements 


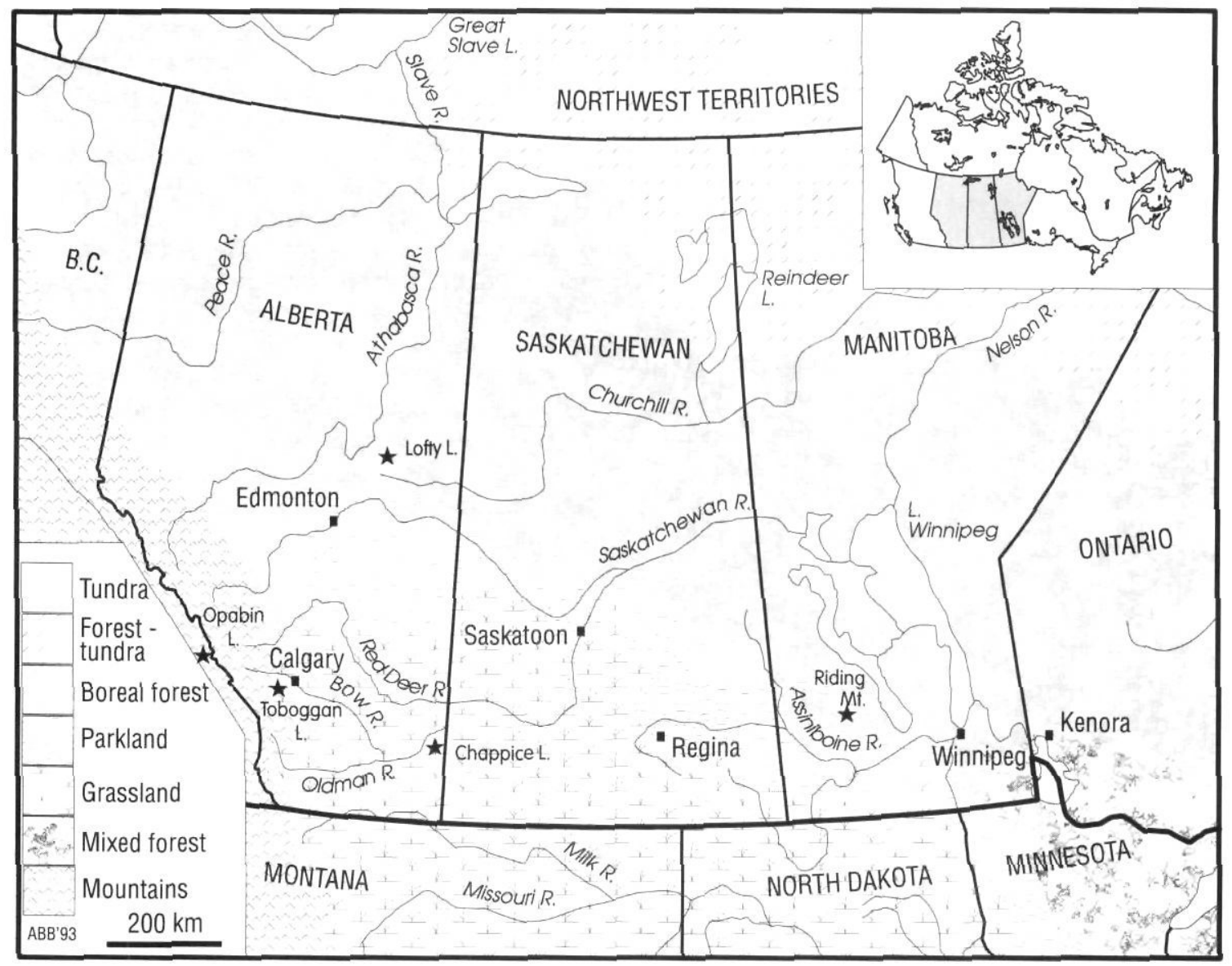

FIGURE 1. Generalized ecological zones (based on Rowe, 1972) and major drainage systems of the Canadian prairie provinces. Major tree species characteristic of each ecological zone: transitional coniferous forest and forest tundra - white spruce (Picea glauca), black spruce (Picea mariana) and tamarack (Larix laricina); boreal forest - white spruce, black spruce, balsam fir (Abies balsamea), jack pine (Pinus banksiana, birch (Betula papyrifera) and aspen (Populus tremuloides); parkland - open woodland with trembling aspen; mixed forest - eastern white pine (Pinus strobus), birch, aspen, Manitoba maple (Acer negundo), and oaks (Quercus spp.). In the mountains, main tree species are lodgepole pine (Pinus contorta var. latifolia) at lower elevations, Engelmann spruce (Picea engelmannii) and subalpine fir (Abies lasiocarpa) at higher elevations. Stars indicate locations of key paleoecological study sites.

are not available for high elevation sites in the mountains, but Janz and Storr (1977) estimate precipitation exceeds $750 \mathrm{~mm} / \mathrm{yr}$ for most areas above treeline. About $70 \%$ of the annual precipitation in the Interior Plains falls between April and September (Laycock,1972). Daily variability is also an important component of western interior climate, with chinook winds (heralding incursions of Pacific air) causing rapid temperature increases in southwestern regions in winter and conversely, southward movement of Arctic air bringing cold temperatures to the prairie provinces in all seasons, particularly in winter months, when temperatures of $-40^{\circ} \mathrm{C}$ are not uncommon.

The prairie provinces span several major ecological zones which, outside the mountains, trend NW-SE following the
Zones écologiques généralisées (fondée sur Rowe, 1972) et principaux réseaux de drainage des provinces des prairies. Arbres dominants caractéristiques de chacune des zones : transition entre la forêt de conifères et la toundra forestière - épinette blanche (Picea glauca), épinette noire (Picea mariana) et mélèze (Larix laricina); forêt boréale - épinette blanche, épinette noire, sapin baumier (Abies balsamea), pin gris (Pinus banksiana), bouleau (Betula papyrifera) et peuplier faux-tremble (Populus tremuloides); tremblaie - parc; forêt mixte - pin blanc (Pinus strobus) bouleau, peuplier faux-tremble, érable négundo (Acer negundo) et chêne (Quercus spp.). En montagne, les principales espèces sont le pin tordu (Pinus contorta var. latifolia) en basse altitude, l'épinette des montagnes Engelmann (Picea engelmannii) et le sapin subalpin (Abies lasiocarpa), en haute altitude.

general course of upper westerly atmospheric flow. The two most extensive vegetation types are the semi-arid grassland in the southern area and the boreal forest in the north (Rowe, 1972; Fig. 1). These two ecozones are separated by the transitional aspen parkland, a mosaic of grassland and aspen groves whose northern limit is the vegetational expression of the mean position of the winter Arctic front (Bryson, 1966). The forest-tundra ecotone bounds the boreal forest to the northeast, occupying the Hudson Bay lowlands of northern Saskatchewan and Manitoba. In the west, elevation is the primary influence on vegetation, with montane coniferous forests in the foothills and lower elevations of the Rocky Mountains, and alpine tundra upslope in the mountains. 


\section{CHRONOLOGY}

Precise identification of the $6 \mathrm{ka}$ interval is not staightforward for several reasons. Radiocarbon dating, the most frequently used technique for chronological control, has an analytical uncertainty associated with each age determination, typically between \pm 75 to \pm 200 years. Additional errors are introduced depending upon the location and type of material dated. These are particularly significant when bulk sediment samples from areas underlain with carbonaceous shale, lignite, and limestone, for example the eastern slopes of the Rocky Mountains (Hickman and Schweger, 1993; White et al., 1985) and the southern prairie grassland (Barnosky et al., 1987; Mott, 1973), are dated by conventional means. Accelerator mass spectrometry (AMS) radiocarbon dating of selected materials, primarily terrestrial plant macrofossils, is the most effective way of circumventing this problem (MacDonald et al., 1987, 1991), but has not yet been used in many studies. Regardless of the dating technique, the $6000 \mathrm{yr}$ BP interval itself is seldom specifically dated. Hence, determination of the $6 \mathrm{ka}$ time slice typically involves interpolation from other (often few) dated horizons, usually when deposition rates are poorly understood. Mazama ash, deposited $6845 \pm 50 \mathrm{yr}$ BP (Bacon, 1983), is a readily recognizable temporal marker in the southwestern portion of the prairie provinces (SarnaWojcicki et al., 1983) and in the mountains, but of course does not clearly identify the $6 \mathrm{ka}$ horizon. Moreover, the existence of possible earlier Mazama eruptions could cause confusion (White and Osborn, 1992; Zoltai, 1989). Besides these analytical and sample errors, there is a significant discrepancy between radiocarbon years and calendar years in the middle Holocene. Due to variations in the production of ${ }^{14} \mathrm{C}$ in the upper atmosphere, a radiocarbon date of 6000 yr BP is actually equivalent to 6850 calendar years (Stuiver and Becker, 1993). Because radiocarbon dates are typically not corrected in the literature and there is considerable potential for errors related to the laboratory procedures and sample type, the $6 \mathrm{ka}$ time slice in this synthesis is broadly defined as the interval between 5000 and 7000 radiocarbon yr BP.

\section{THE PALEOECOLOGICAL RECORD}

The regional pollen stratigraphic record is emphasized in this synthesis because more pollen records are available than any other type of proxy data in the prairie provinces (Fig. 2 and 3). Although 6 ka coverage is uneven, with more sites in Alberta than Saskatchewan and Manitoba combined and the majority situated in boreal forest and mountain environs, the data set is adequate for a preliminary assessment of past vegetation dynamics. However, pollen analysis is a relatively coarse tool for climate reconstruction because: 1) many taxa are identifiable only to the family or genus level (Faegri et al., 1989), resulting in loss of individual species' autecological information, 2) pollen records in western Canada are typically dominated by a few prolific anemophilous taxa, primarily conifers (MacDonald and Ritchie, 1986), that are capable of "drowning out" minor constituents and masking subtle vegetation changes, and
3) some important elements of the regional vegetation are palynologically almost "silent", either because of poor pollen preservation (e.g., Populus, Mott, 1978), inherent low pollen productivity, or entomophily (Moore et al., 1991). Moreover, because of long distance transport and differential deposition and preservation, pollen diagrams integrate data from an unknown area surrounding the site. Not surprisingly, sites located near present-day ecotones show the most clear-cut evidence of past climatic change because they are situated at present day transitions between ecological and climatic zones. Therefore the "broad-brush" picture of environmental conditions available through pollen analysis, although informative in monitoring movement of ecological zone boundaries and major vegetational changes, needs, where possible, to be supplemented with data from other proxy indicators to produce detailed paleoclimatic reconstructions.

\section{A) NORTHERN FOREST TUNDRA}

The northern forest tundra on the northeastern margin of the prairie provinces (Fig. 1) was deglaciated later than the rest of the western interior, then inundated by Glacial Lake Agassiz and subsequently the Tyrrell Sea (Dredge and Cowan, 1989a, b). Therefore much of the land was not available for vegetation colonization until $6 \mathrm{ka}$. There are only two pollen records (Ennadai Lake and Lynn Lake) from this region (Fig. 2), and both begin about 6000 yr BP. On the basis of relic podzols, developed in areas that are presently tundra, and pollen analysis, Nichols (1967) inferred that the northern margin of the boreal forest extended further northward at 6 ka than it does today, suggesting warmer summer temperatures than present.

\section{B) BOREAL FOREST}

Pollen records from within the boreal forest are dominated by the main boreal taxa (Pinus, Picea, Alnus, Betula) and subtle changes in the structure or composition of the forest are difficult to discern. Pollen records from sites within the central boreal forest are relatively complacent during the 6 ka interval (MacDonald, 1984, 1987; Mott, 1973; Nichols, 1969; Kuhry et al., 1992; Matthews, 1980; Ritchie, 1976; Ritchie and Hadden, 1975; Vance, 1986a; Wilson, 1984). Pollen frequency changes in these diagrams relate to migration of species (e.g., jack pine and alder) and forest fires. The most significant change in middle Holocene boreal forest pollen assemblages is an increase in pine. In western Manitoba, Pinus increases from $<5 \%$ to $>40 \%$ abruptly at about 5900 yr BP (Ritchie, 1976). In central Saskatchewan (Cycloid Lake) the increase occurs at $6000 \mathrm{yr}$ BP (Mott, 1973). Further west, the increase in pine pollen is more gradual (e.g., Lofty Lake, Lichti-Federovich, 1970, Fig. 4), and pine is not locally abundant until about $4500 \mathrm{yr}$ BP. This westward migration of jack pine was probably encouraged by frequent fires caused by middle Holocene warmth (Wilson, 1984).

Generally, boreal forest/foothills sites in the northwestern extreme of the prairie provinces do not display substantial changes in pollen frequencies during the $6 \mathrm{ka}$ interval (White and Mathewes, 1982, 1986), although subtle changes 
in indicator taxa suggest the onset of a wetter and cooler climatic regime, compared to that of the early Holocene (Anderson et al., 1989; Schweger and Hickman, 1989). White and Mathewes (1982), on the basis of relatively high Cheno-Am, Typha latifolia, Artemisia, and Gramineae pollen frequencies, suggested that Fiddler's Pond in the Peace
River district, now a perennial lake, was a seasonal pond at $6 \mathrm{ka}$. Since the basin was dry in the early Holocene, $6 \mathrm{ka}$ conditions were cooler and moister than previously, but warmer and possibly drier than present. At nearby Boone Lake, increases in pine pollen around 6 ka suggest that the forests were more fire-prone than they are now (White and

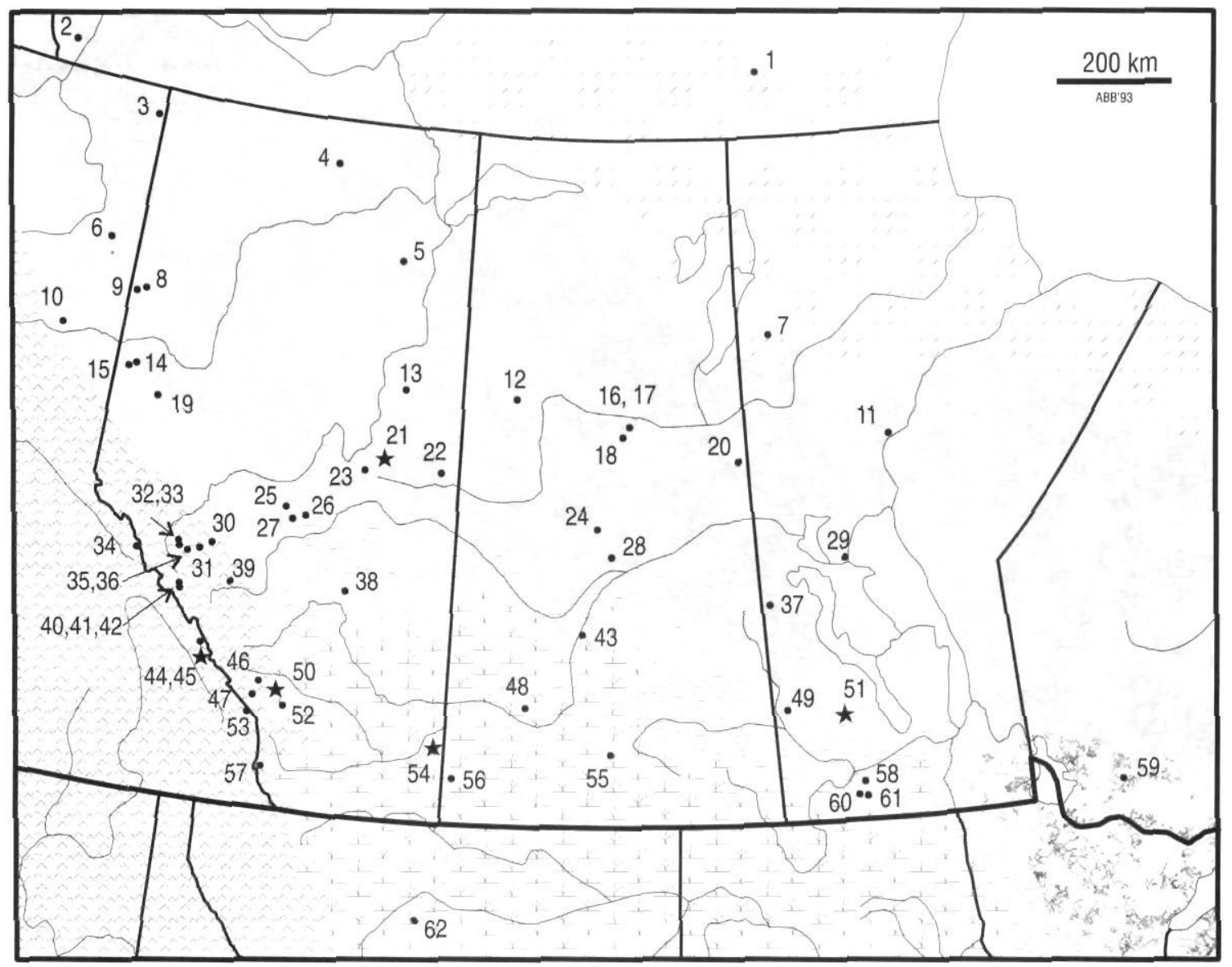

FIGURE 2. Paleoenvironmental records with chronologic control from the prairie provinces and adjacent areas that span the $6 \mathrm{ka}$ interval (7000-5000 yr BP). Most records concentrate on pollen data, some include or focus on macrofossils, geochemistry, or diatoms. For more detail on the Alberta coverage, see Beaudoin (1993).

1. Ennadai Lake (Nichols, 1967), 2. John Klondike Bog (Matthews, 1980), 3. Lac Ciel Blanc (MacDonald, 1984), 4. Wild Spear Lake (MacDonald, 1987), 5. Eaglenest Lake (Vance, 1986a), 6. Snowshoe Lake (MacDonald, 1987), 7. Lynn Lake (Nichols, 1967), 8. Yesterday Lake (MacDonald, 1987), 9. Lone Fox Lake (MacDonald, 1987), 10. Fiddler's Pond (White and Mathewes, 1982), 11. Thompson (Ritchie, 1976), 12. Buffalo Narrows (Kuhry et al, 1993), 13. Mariana Lakes (Nicholson and Vitt, 1990), 14. Boone Lake (White and Mathewes, 1986), 15. Spring Lake (White and Mathewes, 1986; Hickman and White, 1989), 16. West Naniskak Lake (Wilson, 1984), 17. Lake A (Wilson, 1984), 18. Cycloid Lake (Mott, 1973), 19. "Wood Bog" (Beaudoin, unpub.), 20. Flin Flon (Ritchie, 1976), 21. Lofty Lake (Lichti-Federovich, 1970), 22. Moore Lake (Hickman and Schweger, 1993), 23. Alpen Siding (Lichti-Federovich, 1972), 24. Lake B (Mott, 1973), 25. Lake Isle (Hickman and Klarer, 1981), 26. Smallboy Lake (Vance et al., 1983), 27. Wabamun Lake (Hickman et al, 1984), 28. Lake A (Mott, 1973), 29. Grand Rapids (Ritchie and Hadden, 1975), 30. Fairfax Lake (Hickman and Schweger, 1991), 31. Muskiki Lake (Kubiw et al, 1989), 32. Excelsior Basin (Luckman and Kearney, 1986), 33. Watchtower Basin
Données paléoenvironnementales sur les provinces des prairies et les régions avoisinantes avec chronologie bien établie de la période de 6 ka (de 7000 à 5000 BP). La plus grande partie des données concernent la palynologie et certaines comprennent des données sur les macrofossiles, la géochimie et les diatomées.

(Luckman and Kearney, 1986), 34. Tonquin Pass (Kearney and Luckman, 1983), 35. Lorraine Lake (Bear, 1989), 36. Maligne Lake kettle (Kearney and Luckman, 1987), 37. Porcupine Mountain (Nichols, 1969), 38. Buffalo Lake (Schweger and Hickman, 1989), 39. Goldeye Lake (Hickman and Schweger, 1993), 40. Wilcox Pass (Beaudoin and King, 1990), 41. Sunwapta Pass SP-10 (Beaudoin, 1984), 42. Sunwapta Pass SP-1 (Beaudoin, 1984), 43. Martens Slough (Mott and Christiansen, 1981), 44. Lake O'Hara (Reasoner and Hickman, 1989), 45. Opabin Lake (Reasoner and Hickman, 1989), 46. Yamnuska Bog (MacDonald, 1982), 47. Wedge Lake (MacDonald, 1982), 48. Clearwater Lake (Mott, 1973), 49. Russell (Ritchie, 1976), 50. Toboggan Lake (MacDonald, 1989), 51. Riding Mountain (E Lake) (Ritchie, 1964), 52. Chalmers Bog (Mott and Jackson, 1982), 53. Elk Valley Bog A (Hills et al, 1985), 54. Chappice Lake (Vance, 1991), 55. Crestwynd (Ritchie, 1976), 56. Harris Lake (Sauchyn and Sauchyn, 1991), 57. Crowsnest Lake (Hills et al., 1985), 58. Sewell Lake (Ritchie, 1976), 59. Hayes Lake (McAndrews, 1982), 60. Belmont Lake (Ritchie and LichtiFederovich, 1968), 61. Glenboro (Tiger Hills) (Ritchie and LichtiFederovich, 1968), 62. Lost Lake (Barnosky, 1989). 
Mathewes, 1986), because pine (specifically jack or lodgepole pine) regenerates vigorously in burned areas. Frequent middle Holocene forest fires were likely the product of summers warmer and drier than today. Diatom and pigment analyses complement the pollen stratigraphy at a third study site in the Peace River district, Spring Lake
(Hickman and White, 1989). Here too, the 6 ka interval appears transitional between low, warm-water conditions of the early Holocene and higher, more stable water levels achieved by $4800 \mathrm{yr}$ BP. Pine pollen increases at foothills sites further north (Snowshoe and Yesterday Lakes) at about 6 ka (MacDonald, 1984, 1987) reflect the northward

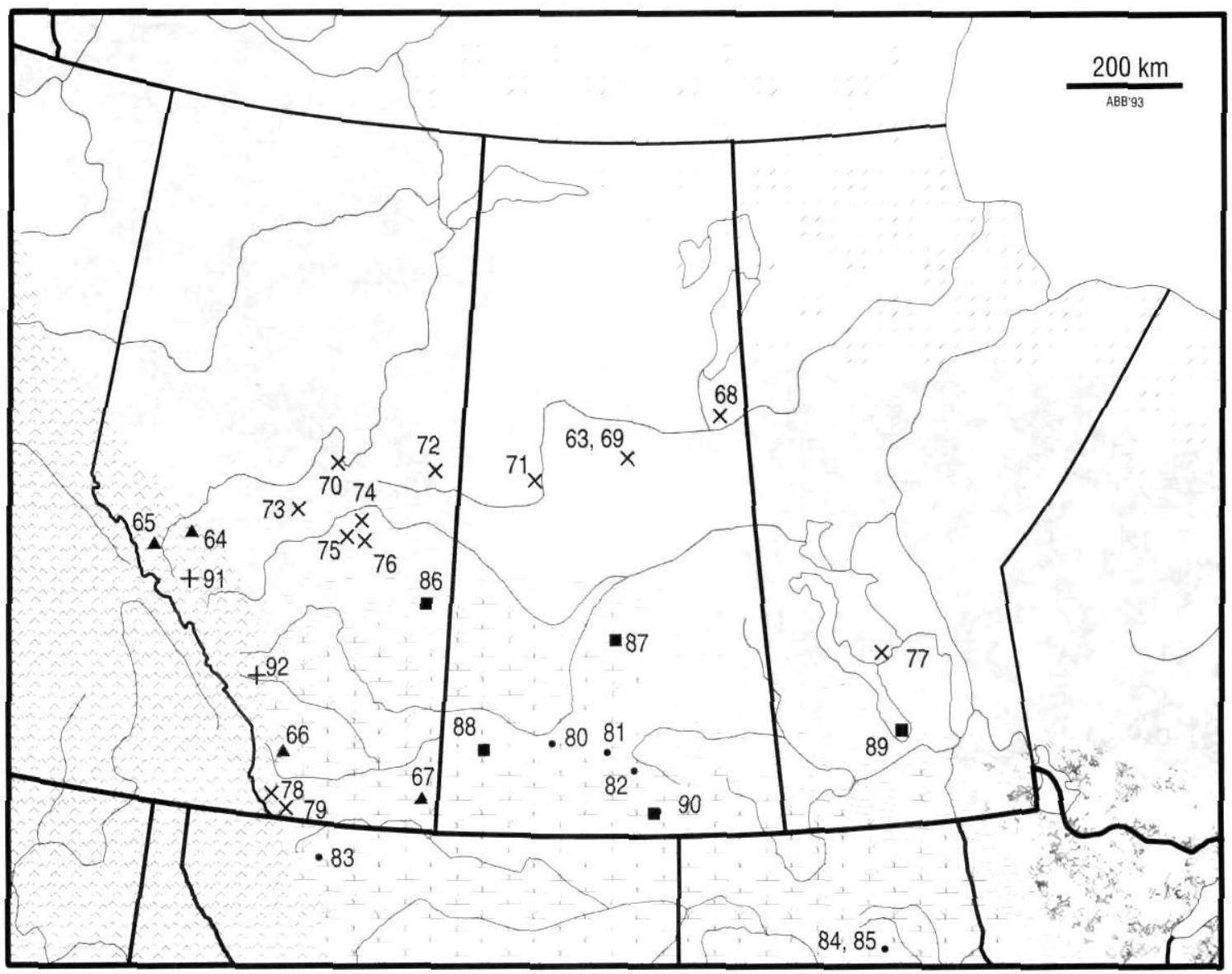

FIGURE 3. Other relevant localities: Records that may span the $6 \mathrm{ka}$ interval but which generally lack firm chronologic control $(\boldsymbol{\Delta})$ : 63. Marl Pond (Wilson, 1984), 64, Mary Gregg Lake (Bombin, 1982), 65. Cottonwood Slough (Kearney, 1981), 66. Callum Bog (Alley, 1972), 67. Elkwater Lake (North, 1992). Records that generally post-date the $6 \mathrm{ka}$ interval $(\mathbf{X})$ : 68 . Reindeer Lake (Ritchie, 1976), 69. La Ronge (Kuhry et al., 1992, 1993), 70. Baptiste Lake (Hickman et al., 1990), 71. Beauval (Kuhry et al., 1993), 72. Marguerite Lake (Kubiw et al., 1989), 73. Lac Ste Anne (Forbes and Hickman 1981), 74. Elk Island Pond (Vance et al., 1983), Elk Island (Kuhry et al., 1993), 75. Cooking Lake (Hickman, 1987), 76. Hastings Lake (Vance et al., 1983), 77. Gypsumville (Kuhry et al., 1993), 78. Goat Lake (Bujak, 1974), 79. Linnet Lake (Hills et al., 1985). Records that pre-date the 6 ka interval (0): 80 . Herbert (Kupsch, 1960), 81. Hafichuk (Ritchie and De Vries, 1964), 82. Kayville (Scrimbit) (Ritchie, 1976), 83. Guardipee Lake (Barnosky, 1989), 84. Woodworth Pond (McAndrews et al., 1967), 85. Siebold (Cvancara et al., 1971). Lake records focused primarily on geochemistry (耳): 86. Metiskow Lake (Last, pers. comm., 1993), 87. Waldsea Lake (Last and Schweyen, 1985), 88. Freefight Lake (Last, 1993), 89. Lake Manitoba (Last and Teller, 1983), 90. Ceylon Lake (Last, 1990). Other localities mentioned in the text (+): 91. Maligne Pass (Luckman and Kearney, 1986), 92. Copper Lake (White and Osborn, 1992).
Autres sites pertinents. Les données concernent la période de 6 ka, mais la chronologie n'est pas rigoureuse (A) : 63. Marl Pond (Wilson, 1984), 64, Mary Gregg Lake (Bombin, 1982), 65. Cottonwood Slough (Kearney, 1981), 66. Callum Bog (Alley, 1972), 67. Elkwater Lake (North, 1992). Les données s'appliquent après la période 6 ka (X) : 68. Reindeer Lake (Ritchie, 1976), 69. La Ronge (Kuhry et al., 1992, 1993), 70. Baptiste Lake (Hickman et al., 1990), 71. Beauval (Kuhry et al., 1993), 72. Marguerite Lake (Kubiw et al., 1989), 73. Lac Ste Anne (Forbes et Hickman 1981), 74. Elk Island Pond (Vance et al., 1983), Elk Island (Kuhry et al., 1993), 75. Cooking Lake (Hickman, 1987), 76. Hastings Lake (Vance et al., 1983), 77. Gypsumville (Kuhry et al., 1993), 78. Goat Lake (Bujak, 1974), 79. Linnet Lake (Hills et al., 1985). Les données précèdent la période 6 ka (@).80. Herbert (Kupsch, 1960), 81. Hafichuk (Ritchie et De Vries, 1964), 82. Kayville (Scrimbit) (Ritchie, 1976), 83. Guardipee Lake (Barnosky, 1989), 84. Woodworth Pond (McAndrews et al., 1967), 85. Siebold (Cvancara et al., 1971). Les données lacustres concernent principalement la géochimie (ם): 86. Metiskow Lake (W.M. Last, comm . pers. , 1993), 87. Waldsea Lake (Last et Schweyen, 1985), 88. Freefight Lake (Last, 1993), 89. Lake Manitoba (Last et Teller, 1983), 90. Ceylon Lake (Last, 1990). Autres sites signalés dans le texte (+): 91. Maligne Pass (Luckman et Kearney, 1986), 92. Copper Lake (White et Osborn, 1992). 


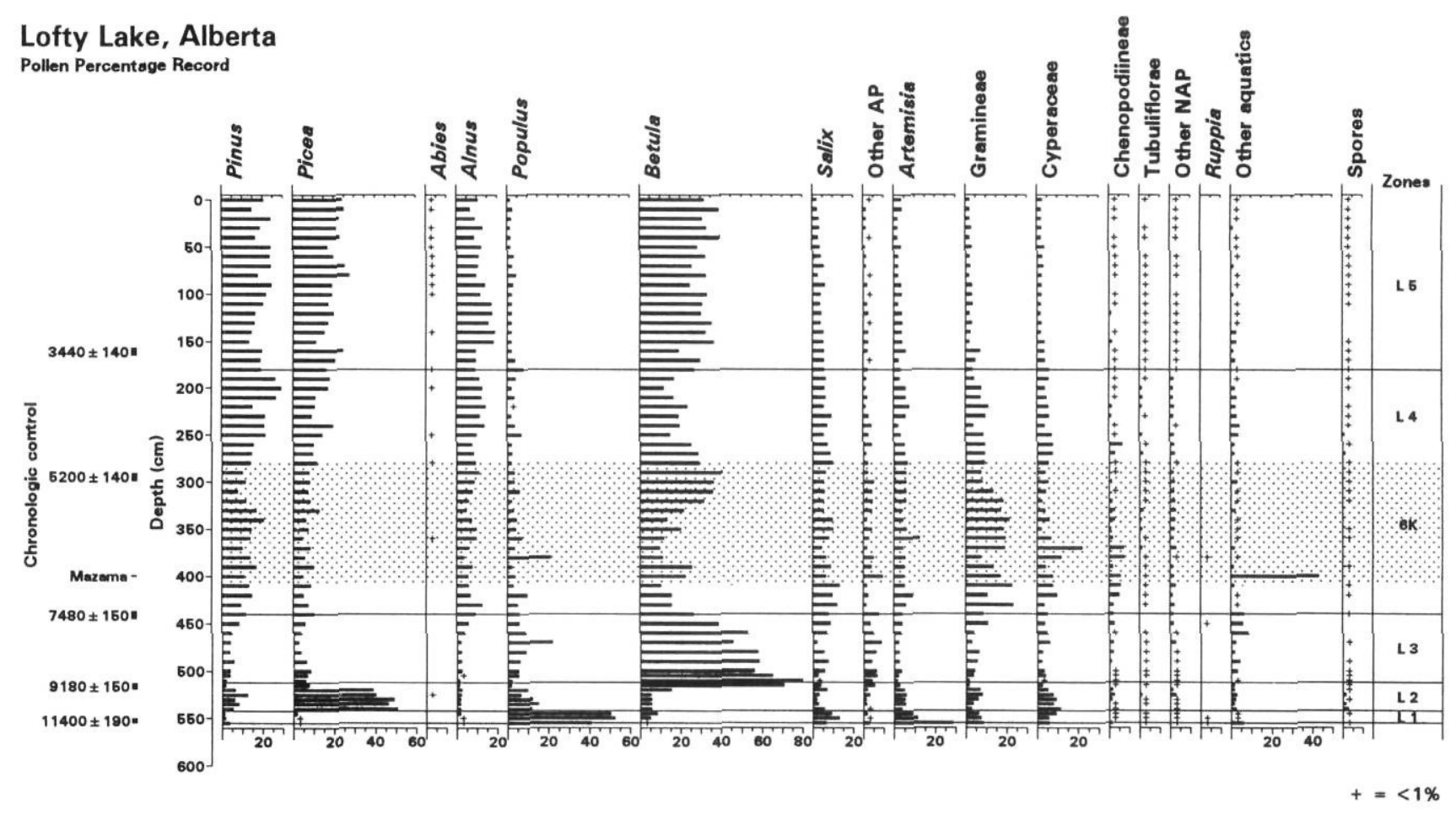

FIGURE 4. Lofty Lake (southern boreal forest, Fig. 2, site 21) summary percentage pollen diagram (Lichti-Federovich, 1970). 6 ka interval (5000-7000 yr BP) shaded. Mazama ash deposited 6850 yr BP (Bacon, 1983).

Holocene expansion of lodgepole pine (Pinus contorta) along the eastern slopes of the Rocky Mountains (MacDonald and Cwynar, 1985).

\section{C) ROCKY MOUNTAIN/FOOTHILLS REGION}

Pollen records from sites in the foothills and montane forest zones of the Rockies are dominated by Pinus and Picea through the majority of the postglacial period. Many (Bear, 1989; Bombin, 1982; Hickman and Schweger, 1991, 1993; Kearney, 1981; Kearney and Luckman, 1987; MacDonald, 1982, 1989; Mott and Jackson, 1982) record only major vegetational changes associated with migration of various taxa following deglaciation and the majority of study sites are situated too far from major ecozone boundaries to register events driven by climatic change. Like the boreal forest, however, the coniferous mountain vegetation is prone to fire, and increased fire frequency at $6 \mathrm{ka}$, compared to today, is implicated in several of these records. Warmer and drier climatic conditions are inferred at lower elevations from middle Holocene maxima in Pinus pollen frequencies (Hills et al., 1985; MacDonald, 1982) and peak charcoal influx (Kearney and Luckman, 1987), both byproducts of frequent fires.

There is also evidence that montane and foothills wetlands may have been under considerable moisture stress during the $6 \mathrm{ka}$ interval, as indicated, for example, by peak carbonate concentration at Yamnuska Bog (MacDonald, 1982). Elevated 6 ka Chenopodiineae and Cyperaceae pollen representation (compared to present), although slightly reduced from peak values achieved at about $8000 \mathrm{yr} \mathrm{BP}$,
Diagramme abrégé de pourcentages polliniques de Lofty Lake (forêt boréale méridionale, fig. 2, site 21) (Lichti-Federovich, 1970). L'intervalle de 6 ka (5000-7000 BP) est tramé. La cendre du mont Mazama a été déposée à 6850 BP (Bacon, 1983).

suggests lower water levels than today at Toboggan Lake (Fig. 5a). Kubiw et al. (1989) noted changes in peat type and macrofossil assemblages at Muskiki Lake that indicate lowering of the water table between about $7500-4500 \mathrm{yr} \mathrm{BP}$, and suggested that incursions of moist Pacific at this time may have been crucial for maintaining wetlands in the foothills, albeit with a lower water table than today, when sites further east were dry.

In the mountains, however, the clearest indication of warmer than present 6 ka climate is the upslope migration of the temperature-sensitive upper subalpine treeline. Pollen records from subalpine and alpine areas in the Alberta Rockies (Beaudoin, 1986; Beaudoin and King, 1990; Kearney and Luckman, 1983; Luckman and Kearney, 1986; Reasoner and Hickman, 1989) all suggest higher than present timberlines during the middle Holocene. For example, the pollen and plant macrofossil record from Opabin Lake (Fig. $5 b)$, a glacier-fed basin now situated above timberline in the southern Canadian Rockies, shows an extended period of increased Picea and Abies pollen and needle input between 7000 and $3000 \mathrm{yr}$ BP. Clearly, treeline was positioned upslope of the lake at this time in response to elevated summer temperatures, compared to today. Peak diatom productivity at Opabin Lake (7000 and 5500 yr BP) supports this interpretation (Reasoner and Hickman, 1989), because diatom proliferation in alpine lakes reflects favourable, warm water growing conditions.

Abundant subfossil wood in alpine areas also suggests higher than present treeline during the 6 ka interval. Luckman 


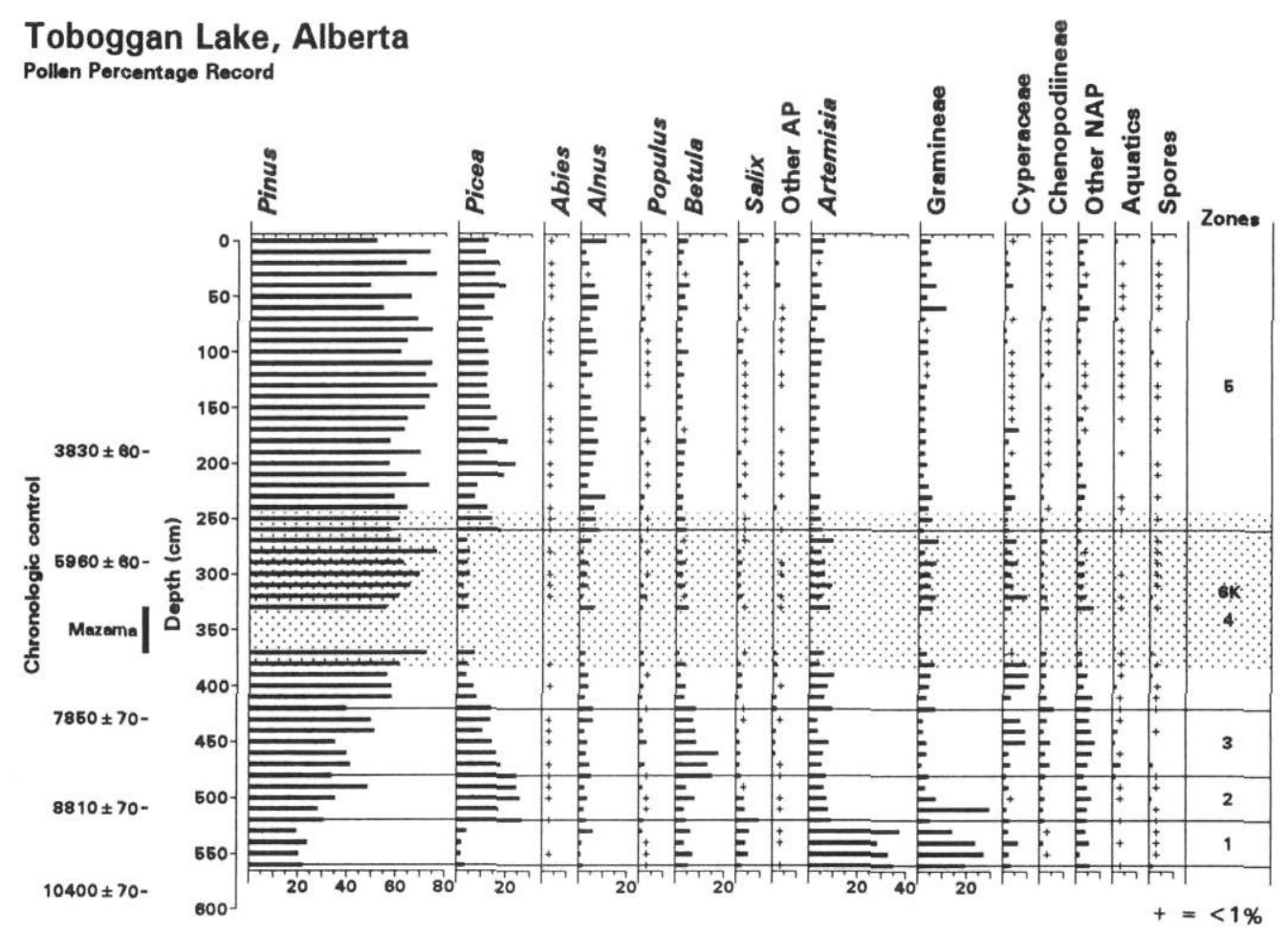

FIGURE 5a) Toboggan Lake (foothills subalpine forest, Fig. 2, site 50$)$ summary percentage pollen diagram (MacDonald, 1989).

a) Diagramme abrégé de pourcentages polliniques de Toboggan 6 ka interval (5000-7000 yr) shaded. Mazama ash deposited 6850

Lake (forêt subalpine de piémont, fig. 2, site 50) (MacDonald, BP (Bacon, 1983).

1989). L'intervalle de 6 ka (5000-7000 BP) est tramé. La cendre du mont Mazama a été déposée à 6850 BP (Bacon, 1983).

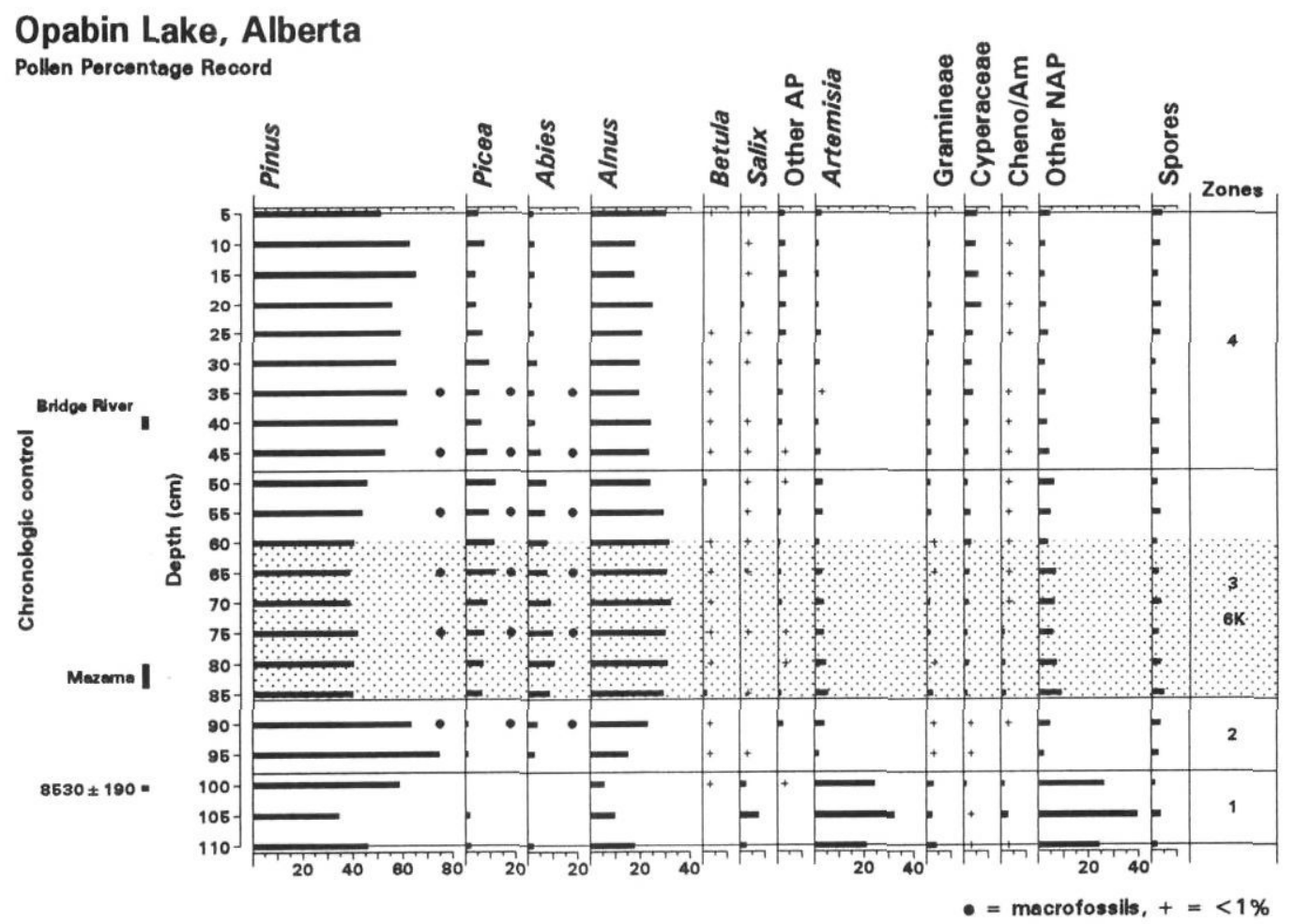

FIGURE 5b) Opabin Lake (alpine tundra, Fig. 2, site 45) summary percentage pollen diagram, including occurrence of macrofossils indicative of treeline proximity. $6 \mathrm{ka}$ interval $(5000-7000 \mathrm{yr}$ BP) shaded. Mazama ash deposited 6850 yr BP (Bacon, 1983); Bridge River ash deposited 2350 yr BP (Mathewes and Westgate, 1980). b) Diagramme abrégé de pourcentages polliniques de Opabin Lake (toundra alpine, fig. 2, site 45), comprenant la présence de macrofossiles indicatifs de la proximité de la ligne des arbres. L'intervalle de 6 ka (5000-7000 BP) est tramé. La cendre du mont Mazama a été déposée à $6850 \mathrm{BP}$ (Bacon, 1983); la cendre de Bridge River a été déposée à 2350 BP (Mathewes et Westgate, 1980). 
and Kearney (1986) report Picea logs dated ca. 7910, 8060 and $8770 \mathrm{yr}$ BP approximately $100 \mathrm{~m}$ above present treeline in the Watchtower Basin of the Maligne Range. Picea, Abies, and Pinus needles were also recovered from sediment older than $5960 \mathrm{yr}$ BP at this site. Further south, two large Abies logs were recovered from a site $50 \mathrm{~m}$ above present treeline in Maligne Pass and dated to 5960 and 5260 yr BP (Table I). These sub-fossil trees were over 3.5 $\mathrm{m}$ long and were found with rootstocks attached, indicating that they were buried in situ. Differences in size and ringwidth characteristics between these subfossil and contemporary trees (see Luckman and Kearney, 1986, Table 2) indicate that the subfossil trees were probably growing some distance below the contemporaneous treeline.

Warmer, and probably drier conditions than present also allowed forest to colonize upper mountain valley floors now occupied by wetlands. For example, subfossil trees have been recovered from two sites (Tonquin Pass and Sunwapta Pass) located below present treeline that are currently too wet for tree growth. Stumps and logs recovered below Mazama tephra from sections in Tonquin Pass (Kearney and Luckman, 1983; Luckman, 1990, Fig. 4) date to between 4400 and $6570 \mathrm{yr}$ BP. Because there is little possibility that stream or avalanche activity could have transported these trees to their present location (the largest log is over $7 \mathrm{~m}$ long), these logs indicate that the valley floors were dry enough to support tree growth at $6 \mathrm{ka}$. Logs ranging in age from 5160 to $8100 \mathrm{yr}$ BP (Table I) were also recovered from peats in Sunwapta Pass. Detrital peat layers with abundant cones and twigs have been dated to between 8100 and $6900 \mathrm{yr}$ BP in two of these wetlands, again suggesting somewhat drier than present conditions between 5000 and $8000 \mathrm{yr}$ BP. Wood dates from high elevation sites (Table I) show two groupings at $5000-6600 \mathrm{yr} \mathrm{BP}$ and $7500-8800 \mathrm{yr}$ BP. These correspond broadly with the two periods of highest treeline position shown in the reconstructed treeline curve, based on Abies/Pinus pollen ratios in the Watchtower Basin (Luckman and Kearney, 1986).

Recent dating of the Crowfoot Advance (Luckman and Osborn 1979) to the interval between 10,100 and $11,300 \mathrm{yr}$ BP (Reasoner et al., 1993), indicates that glaciers had receded, by $10,000 \mathrm{yr} \mathrm{BP}$, to positions that were not surpassed until the Little Ice Age (ca. $600 \mathrm{yr}$ BP). The inference that glaciers were less extensive than today during the $6 \mathrm{ka}$ interval is supported by middle Holocene sedimentation rate minima in glacier-fed Crowfoot Lake, because low rates indicate reduced glacial sediment input (Leonard, 1986). Recently, detrital wood, derived from subglacial sources and dating to between 6100 and $6400 \mathrm{yr}$ BP, has been washed out of the snout of Dome Glacier (Table I, Luckman et al., 1993). The wood recovered includes fragments from mature, erect trees, at least $30 \mathrm{~cm}$ in diameter and 200-300 years old, that was being reworked from a deposit at an unknown location some distance up-valley. It indicates that $\mathrm{ca} .6000-6400 \mathrm{yr}$ BP there were mature pines growing on the valley floor or lower valley side sites of the Dome Valley in an area which is presently ice-covered. Similar material has been recovered from the adjacent
Athabasca Glacier but ranges in age from 7550-8230 yr BP (Table I, Luckman, 1988; Luckman et al., 1993). Based on the microclimate and colonization patterns in the present forefields of these glaciers, it seems probable that the termini of Athabasca and Dome Glaciers were probably several kilometres up-valley of their present positions during the $6 \mathrm{ka}$ interval. Warmer 6 ka summer temperatures could also have produced higher summer runoff volumes in glacier-fed rivers that cross the prairies. Such downstream effects must be considered when evaluating paleoenvironmental conditions at riparian sites along the major prairie rivers.

Pollen records from lower treeline sites, particularly in southwestern Alberta where the transition from subalpine to grassland vegetation takes place over a relatively short distance, show that coniferous forest retreated to higher elevations as grassland expanded upslope at 6 ka (Hills et al., 1985; MacDonald, 1989). These ecotonal adjustments suggests increased aridity compared to today, an interpretation that is supported by compositional changes in the local vegetation. For example, at Toboggan Lake, increased amounts of Haploxylon-type pine pollen between 7600-5500 yr BP probably represent the establishment of limber pine (Pinus flexilis) near the site (MacDonald, 1989). Limber pine is currently restricted to dry, rocky, lower treeline sites, such as those along the east slopes of the Rocky Mountains ca. $75 \mathrm{~km}$ south of Toboggan Lake. Middle Holocene increases in nonarboreal pollen frequencies indicate that grassland expanded upslope from its current position on the plains into floors of major valleys in the extreme southwest of the study area at 6 ka (Hills et al., 1985), once again suggesting that 6 ka climate was warmer and drier than present.

\section{D) SOUTHERN BOREAL FOREST, PARKLAND}

Sites near the southern boreal forest margin and the aspen parkland display the most clear-cut evidence of $6 \mathrm{ka}$ vegetation change in the western Canadian interior. In the west, many records (Hickman et al., 1984; Hickman and Schweger, 1993; Lichti-Federovich, 1970, 1972; Vance et al., 1983) show that grassland expanded north of its current limit at this time. At Lofty Lake (Lichti-Federovich, 1970), a standard for discussing the vegetation history of western Canada (Fig. 4), the 6 ka interval falls within zone L4 (7500$3500 \mathrm{yr} B P$ ). The distinguishing feature of L4 is increased nonarboreal pollen (especially Gramineae and to a lesser extent Artemisia, Cyperaceae, and Chenopodiineae). These changes suggest local expansion of open grassy areas on xeric, south-facing slopes accompanied by movement of the prairie grassland margin some $80 \mathrm{~km}$ to the north of its current limit (Lichti-Federovich, 1970). Lofty Lake was considerably reduced in size between 8700-6300 yr BP, suggesting that water level fell by as much as $8 \mathrm{~m}$ (Anderson et al., 1989; Schweger and Hickman, 1989). This event probably accounts, at least in part, for the heightened Cyperaceae representation early in zone L4.

Other sites in the southern boreal forest/parkland of Alberta show that a regional drop in the water-table accompanied the middle Holocene northward movement of 
TABLE ।

Wood older than ca. 4000 yr BP, Jasper National Park, and adjacent area

\begin{tabular}{|c|c|c|c|}
\hline Radiocarbon date & Lab. number & Species/material & Comments \\
\hline \multicolumn{4}{|l|}{ Watchtower Basin } \\
\hline $8770 \pm 80$ & GSC 3195 & Picea & $\begin{array}{l}\text { Logs recovered from bog } 100 \mathrm{~m} \text { above present treeline } \\
\text { (Luckman and Kearney, 1986). }\end{array}$ \\
\hline $8060 \pm 90$ & GSC 2615 & Picea & \\
\hline $7910 \pm 70$ & GSC 3226 & Picea & \\
\hline \multicolumn{4}{|l|}{ Sunwapta Pass } \\
\hline $8100 \pm 100$ & GSC 2589 & Picea & $\begin{array}{l}\text { Logs recovered from Bog } 2 \text { in Sunwapta Pass } \\
\text { (Beaudoin, 1984) }\end{array}$ \\
\hline $7700 \pm 110$ & BGS 450 & Picea & \\
\hline $5160 \pm 60$ & GSC 3356 & Picea & \\
\hline $6920 \pm 100$ & BGS 451 & Peat & $\begin{array}{l}\text { Detrital layer with wood and cones, Bog } 4 \\
\text { (Beaudoin, 1984) }\end{array}$ \\
\hline $6850 \pm 100$ & AECV-324C & Peat & \\
\hline \multicolumn{4}{|l|}{ Tonquin Pass } \\
\hline $6570 \pm 70$ & GSC 2468 & Picea & $\begin{array}{l}\text { Logs or stems from small wetland in Tonquin Pass } \\
\text { (Kearney and Luckman, 1983; Lowden and Blake, 1980) }\end{array}$ \\
\hline $5090 \pm 70$ & GSC 2631 & Picea & \\
\hline $4400 \pm 200$ & GSC 2927 & Picea & \\
\hline \multicolumn{4}{|l|}{ Maligne Pass } \\
\hline $5920 \pm 70$ & BGS 566 & Abies & $\begin{array}{l}\text { Logs from small wetland } 50 \mathrm{~m} \text { above present treeline } \\
\text { (Luckman and Kearney, 1986) }\end{array}$ \\
\hline $5260 \pm 100$ & GSC 3147 & Abies & \\
\hline \multicolumn{4}{|l|}{ Athabasca Glacier } \\
\hline $8230 \pm 80$ & Beta 17373 & Pinus & $\begin{array}{l}\text { Shredded wood samples washed from Athabasca } \\
\text { Glacier (Luckman, 1988; Luckman et al., 1993) }\end{array}$ \\
\hline $8000 \pm 90$ & Beta 20047 & ?Pinus & \\
\hline $7550 \pm 100$ & Beta 29957 & ?Pinus & \\
\hline $\begin{array}{l}\text { Dome Glacier } \\
6380 \pm 80\end{array}$ & Beta 33008 & Pinus & $\begin{array}{l}\text { Detrital wood washed from Dome Glacier } \\
\text { (Luckman et al., 1993) }\end{array}$ \\
\hline $6120 \pm 60$ & Beta 33007 & Pinus & \\
\hline
\end{tabular}

$\mathrm{AECV}=$ Vegreville, Alberta: Beta $=$ Beta analytic, Florida; $B G S=$ Brock University; $\mathrm{GSC}=$ Geological Survey of Canada

grassland. Basal dates from peatlands suggest that a low water-table, compared to today, inhibited development of fen peat before 6 ka throughout much of the present southern boreal forest (Zoltai and Vitt, 1990). Numerous basal radiocarbon dates on lake sediment sequences reveal that many basins remained dry in central Alberta at $6 \mathrm{ka}$, although infilling of some of the previously dry basins had begun as early as $7500 \mathrm{yr}$ BP (Schweger and Hickman, 1989). Deeper basins that retained water through the early Holocene arid interval remained significantly reduced in size and more saline at $6 \mathrm{ka}$ than they are today, an interpretation based on several lines of evidence: the presence of Ruppia pollen (Schweger and Hickman, 1989), an aquatic taxon that thrives in saline water (Husband and Hickman, 1985); diatom assemblages suggesting reduced water levels (Hickman and Klarer, 1981; Hickman et al., 1984, 1990; Hickman and Schweger, 1993; Schweger and Hickman, 1989); and peak carbonate production likely stimulated by decreased water levels (Hickman and Klarer, 1981). Peak charcoal input also suggests that fires were more prevalent than today (Hickman et al., 1984; Anderson et al., 1989; Schweger and Hickman, 1989). Lakes that maintained permanent water through 6 ka were probably fed by dependable, deep groundwater sources, as at Lake Wabamun (Hickman et al., 1984). In summary, conditions remained warmer and drier than present throughout central Alberta at $6 \mathrm{ka}$.

To the east, a similar northward movement of grassland at $6 \mathrm{ka}$ is evident from peak nonarboreal pollen input at scattered sites in Saskatchewan and Manitoba (Mott, 1973; Mott and Christiansen, 1981; Ritchie, 1964, 1969, 1976; Ritchie and Lichti-Federovich, 1968; Wilson, 1984). Zone II pollen representation at E Lake in Riding Mountain (Ritchie, $1964,1966,1969,1983)$ typifies the nature of vegetation changes that occurred in the southern boreal forest/parkland of these provinces (Fig. 6). Artemisia, Ambrosia, and Cheno-Am pollen frequencies are declining, but remain higher than present. In contrast, Picea pollen representation is much lower than present. These changes indicate that forested uplands on Riding Mountain were occupied by 

Riding Mountain, Manitoba
Pollon Porcentage Record

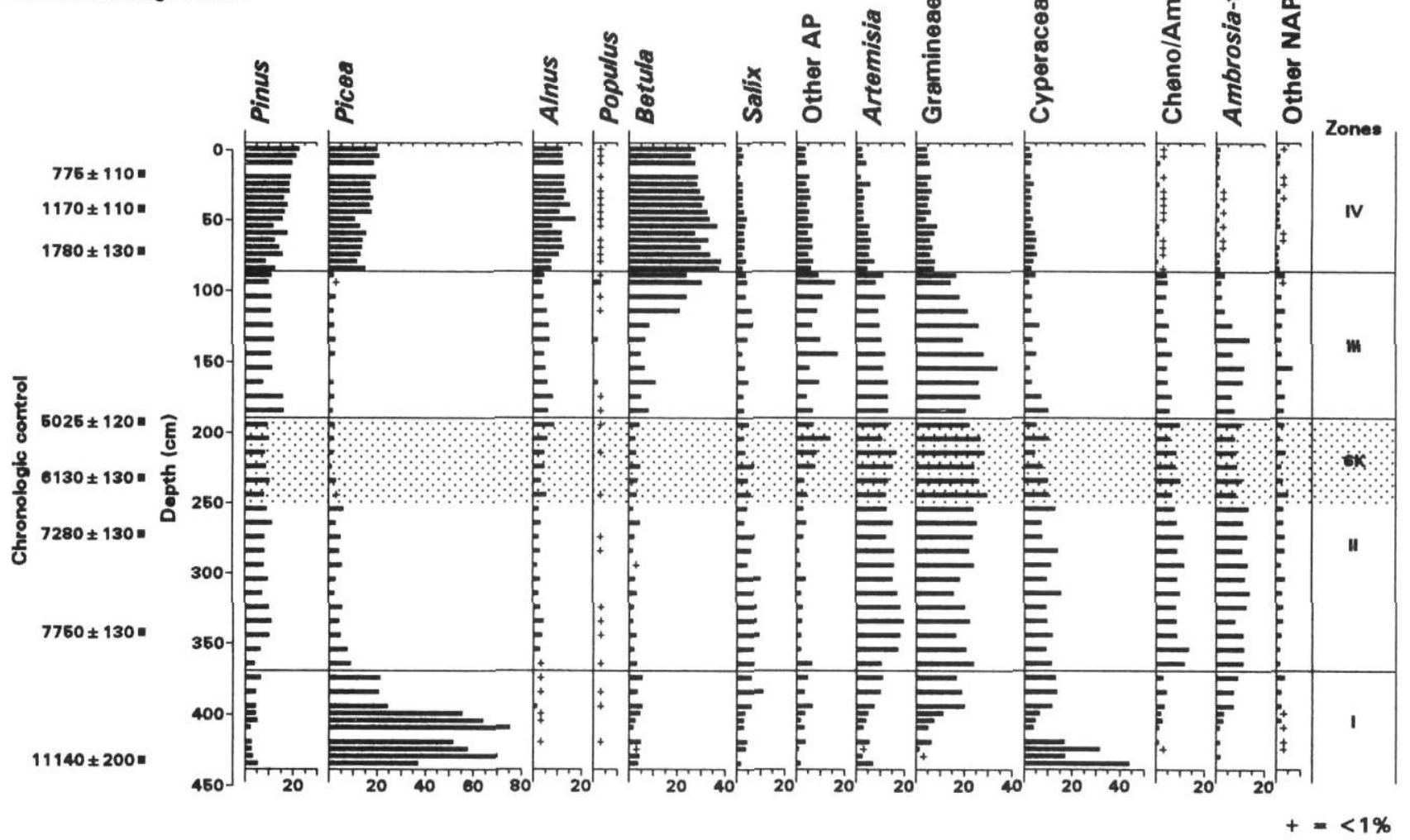

FIGURE 6. Riding Mountain (southern boreal forest, Fig. 2, site 51) summary percentage pollen diagram (Ritchie, 1964). $6 \mathrm{ka}$ interval (5000-7000 yr BP) shaded.

grassland at $6 \mathrm{ka}$ in response to warmer and drier climatic conditions. Similar events are evident in pollen records from southern Manitoba, where grassland replaced parkland in the middle Holocene (Ritchie and Lichti-Federovich, 1968), and in northwestern Ontario, where parkland replaced boreal forest (McAndrews, 1982). Higher evapotranspiration rates resulting from either higher summer temperatures or reduced precipitation (or both) are implicated in these records on the eastern prairie margin.

As in central Alberta, middle Holocene lake levels were lower than today in central Saskatchewan. Waldsea Lake, currently $14 \mathrm{~m}$ deep at its deepest point, was a shallow saline playa at $6 \mathrm{ka}$ (Last, pers. comm., 1993, Last and Schweyen, 1985). Detailed lithostratigraphic studies of numerous core samples from Lake Manitoba, one of the largest lakes in the prairie provinces (Fig. 1), indicate that the lake was considerably shallower during the 6 ka interval (the lake now has a maximum depth of $6 \mathrm{~m}$ ) and, at times, the south basin was completely dry (Last and Teller, 1983; Teller and Last, 1990). These hydrological adjustments suggest more arid conditions than today also prevailed over central Saskatchewan and southern Manitoba at $6 \mathrm{ka}$.

\section{E) GRASSLAND}

Paleoecological studies in the southern reaches of the prairie provinces should provide a particularly sensitive record of effective precipitation, since the distribution of
Diagrammme abrégé de pourcentages polliniques de Riding Mountain (forêt boréale méridionale, fig. 2, site 51) (Ritchie, 1964). L'intervalle de 6 ka (5000-7000 BP) est tramé.

grassland is mainly determined by available moisture. Unfortunately, pollen records from the grassland region are rare, and several records that have been studied are either truncated and restricted to the early Holocene (Ritchie and DeVries, 1964), or lack chronological control (Ritchie, 1976). In addition, errors in conventional radiocarbon ages are chronic due to widespread carbonate deposits (Barnosky et al., 1987; Mott,1973). However, AMS radiocarbon dating at two recently studied sites in the driest portion of the western interior provides the first reliable chronology of Holocene paleoecological events in the prairie grassland.

Harris Lake is a small, freshwater basin situated at lower treeline on the northern flank of the Cypress Hills, a forested enclave in southwestern Saskatchewan. Pollen and lithostratigraphic studies indicate that, although preceded by a period when lake level was lower than today (9100$7700 \mathrm{yr} \mathrm{BP}$ ), the $6 \mathrm{ka}$ interval is characterized by grassland dominance of the local vegetation (Sauchyn and Sauchyn, 1991) and mineralogical changes indicative of periodic low water interludes when lake salinity rose considerably above present values (Last and Sauchyn, 1993). However, unlike many lakes in the grassland, Harris Lake did not dry up during the $6 \mathrm{ka}$ interval, as indicated by the continued occurrence Myriophyllum pollen.

Chappice Lake is a small, shallow, hypersaline lake in the mixed-grass prairie of southeastern Alberta, $75 \mathrm{~km}$ northwest of Harris Lake. The Chappice Lake pollen record has 
limited interpretive value because it is dominated by Artemisia, Gramineae, and Chenopodiineae, three taxa that include a number of species with widely varying tolerances that cannot be distinguished on the basis of pollen. Nevertheless, aspects of the record suggest that the $6 \mathrm{ka}$ interval marks the transition from a lengthy period of pronounced water level fluctuations (indicated by heightened Cheno-Am and Ambrosia percentages and fluctuating Ruppia representation) to an interval of more stable, low-water, hypersaline conditions, as indicated by peak Ruppia frequencies (Vance, 1991; Vance et al., 1992, 1993). This transition is also expressed in sediment type. Prior to 6000 $\mathrm{yr}$ BP, massive and laminated silt and clay sequences punctuate units of well sorted silt and fine sand, the latter most likely deposited during intervals of intense aeolian activity when the basin was dry. From 6000 to $5000 \mathrm{yr}$ BP, sediments are composed mainly of finely laminated carbonate-rich mud. Plant macrofossil remains (Fig. 7) are rare in pre6000 yr BP sediment, a reflection of poor environment for preservation due to exposure and oxidation during lake desiccation, but abundant in sediment deposited between 6000 and $5000 \mathrm{yr}$ BP. Here, high Ruppia seed and Chara oogonia concentrations indicate the presence of hypersaline, carbonate-rich waters; whereas an abundance of Chenopodiinaeae, Cyperaceae, and Gramineae seeds suggest that the lake was smaller than present, although more productive than previously, as indicated by peak loss-onignition values (Vance, 1991).

Other grassland paleolimnological records are equivocal with regard to widespread low-water conditions during the 6 ka interval. Sedimentological studies of numerous cores suggest that Ceylon Lake, a saline playa in southern Saskatchewan, may have been dry at times through the $6 \mathrm{ka}$ interval, but also may have periodically attained high levels (Last, 1990; Teller and Last, 1990). Guliov (1963) used ostracode remains to outline a period of reduced water levels (7000-4000 yr BP) in a small prairie pond near Regina. Mott's (1973) pollen record from Clearwater Lake in southwestern Saskatchewan also suggests increased 6 ka aridity, compared to today. In contrast, near-shore sedimentary records from Freefight Lake, a deep, hypersaline lake less than $125 \mathrm{~km}$ from Clearwater Lake, suggest that the lake was maintained at levels as high as today through the middle Holocene (W.M. Last, pers. comm., 1993). Metiskow Lake, a playa situated at the grassland/parkland boundary in eastern Alberta, was a hypersaline perennial (but shallow) lake during the 6 ka interval (W.M. Last, pers. comm., 1993). These contradictory interpretations are difficult to reconcile in light of previously discussed studies that suggest conditions drier than present were widespread throughout much of the western Canadian interior during the middle Holocene. It is possible that this variablility is related to local groundwater characteristics, a significant but poorly understood aspect of prairie wetland hydrology (Last and Slezak, 1986). Alternatively, the varied interpretations may be more apparent than real because chronologies at most sites are based on conventional radiocarbon ages that could be in error by a millennium or more. It is clear however, that the $6 \mathrm{ka}$ interval was followed by a period of widespread basin infilling and lake freshening throughout much of the southern grassland, beginning about 4000 yr BP (Vance and Last, 1994).

Paleoecological records from terrestrial sites are even more rare than lacustrine records in the grassland, but the few existing studies have important implications for 6 ka climate reconstructions. Bryan et al. (1987) noted numer-

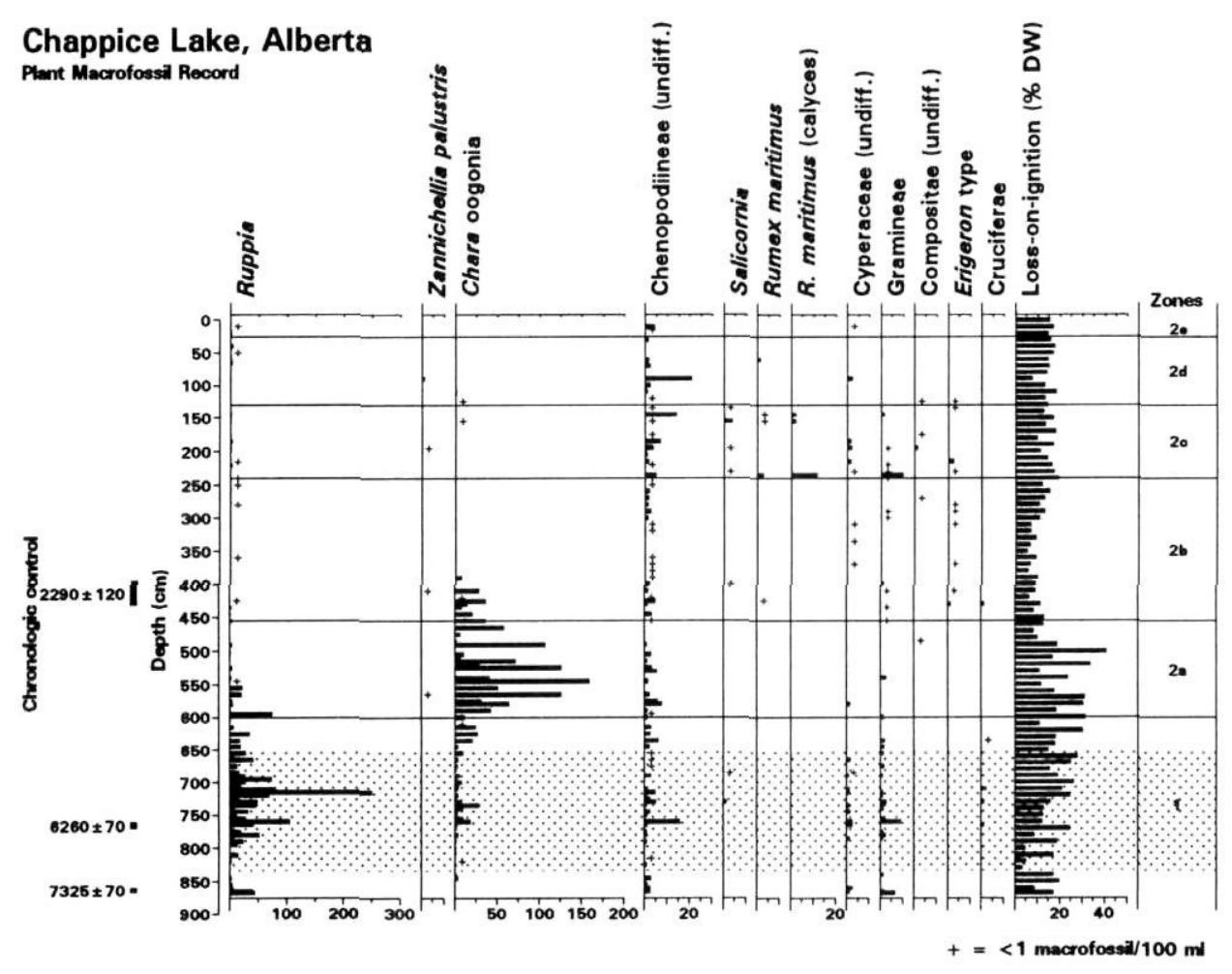

FIGURE 7. Chappice Lake (grassland, Fig. 2, site 54) plant macrofossil concentration (fossils/ $100 \mathrm{ml}$ ) record (Vance, 1991). 6 ka interval (5000-7000 yr BP) shaded.

Concentration de plantes macrofossiles (fossiles 100/ml) à Chappice Lake (prairie, fig. 2, site 54) (Vance, 1991). L'intervalle de 6 ka (5000-7000 BP) est tramé. 
ous aeolian silt and fine sand deposits in Dinosaur Provincial Park, southern Alberta. Material from the base of one of these units yielded a thermoluminescence date of $5400 \pm 800$ yr BP, suggesting that the $6 \mathrm{ka}$ interval was marked by increased levels of aeolian activity in southern Alberta compared to today. This conclusion is supported by geological and archaeological studies in the Bow River valley near Calgary, where extensive loess units, deposited between 8000 and 5000 yr BP, have been described (Wilson, 1983; pers. com. 1993). Evidence from prairie sloughs and dugouts in Alberta (Beaudoin, 1992), Saskatchewan (Mott and Christiansen, 1981) and North Dakota (Cvancara et al., 1971, McAndrews et al., 1967) indicates that freshwater conditions prevailing immediately after deglaciation were followed by middle Holocene drying and substantial aeolian input. Aridity and reduced vegetation cover, accompanied by high winds and likely frequent fires, appear to have stimulated considerable sediment redistribution during the $6 \mathrm{ka}$ interval.

Pedologic studies in southwestern Alberta river basins have revealed a period of reduced alluvial deposition and soil development prior to the Mazama ash fall, indicating reduced flooding compared to present, presumably reflecting drier conditions (Waters and Rutter, 1984). Other investigators have reported pre-Mazama paleosols in the southern prairies (e.g., Kingston, 1982; Pennock and Vreeken, 1986; Reeves and Dormaar, 1972) that are indicative of repeated episodes of landscape stability. These features were subsequently buried by clastic influx from increased erosion during the 6 ka interval. Reeves and Dormaar (1972) suggested that a paleosol deposited ca. $8000 \mathrm{yr}$ BP probably developed during cooler, moister conditions. Collectively, these studies indicate that the 6 ka interval was preceded by a variable climatic regime, where prevailing warm and dry conditions were punctuated by moist interludes.

\section{QUANTITATIVE ESTIMATES OF PAST CLIMATE}

Numerous records cited above indicate that the upper limit of tree growth in the Rocky Mountains increased during the $6 \mathrm{ka}$ interval. Because treeline elevation is controlled mainly by temperature (Kearney, 1982), high-elevation sites offer sensitive records of Holocene temperature changes that may be readily translated into estimates of past temperature excursions. For example, assuming contemporary lapse rates, the reconstructed treeline $100 \mathrm{~m}$ higher than present at Watchtower Basin indicates that mean annual temperature was at least $0.5^{\circ} \mathrm{C}$ warmer than present at 6 ka (Luckman and Kearney, 1986). Most of this increase is probably due to warmer growing season temperatures. Abies/Pinus pollen ratio evidence of treeline movement in the Excelsior Basin suggest 6 ka mean July temperatures were ca. $0.7^{\circ} \mathrm{C}$ warmer than present (Luckman and Kearney, 1986). Oxygen isotope analyses of large Abies subfossil logs found above present treeline at Maligne Pass indicate that mean annual temperatures were between $1.25^{\circ}$ and $1.6^{\circ} \mathrm{C}$ warmer than today between 5300 and $6000 \mathrm{yr}$ BP (Luckman and Kearney, 1986).
Quantitative estimates of past climatic changes based on transfer functions have been developed from two pollen records in the southern Boreal Forest. These reconstructions from Riding Mountain, Manitoba (Ritchie, 1983), and Lofty Lake, Alberta (Vance, 1986b), should be viewed with caution, since Holocene plant migrations (and other factors) can produce pollen assemblages with no known modern analogue, a situation that undermines the entire procedure. Furthermore, the transfer functions applied to the Lofty Lake pollen record do not reproduce modern conditions accurately, particularly in terms of growing season precipitation. Bearing these caveats in mind, however, a preliminary assessment of growing season temperature and precipitation changes at these two study sites is possible.

Both the Lofty Lake and Riding Mountain estimates suggest that growing season (May-August) temperature rose rapidly ca. 10,000 yr BP and remained above present values throughout most of the Holocene. The magnitude and timing of peak temperatures vary considerably, however. The Lofty Lake record indicates that growing season temperature was about $1.5^{\circ} \mathrm{C}$ warmer than present from 9000 to $6000 \mathrm{yr} \mathrm{BP}$, whereas the Riding Mountain record suggests that peak conditions were attained between 6000 and 3000 yr BP, when growing season temperature exceeded current conditions by $6^{\circ} \mathrm{C}$. Although differences in the timing of peak Holocene warmth may in some way be a reflection of atmospheric circulation dynamics, it is unlikely that the temperature differences are realistic. Because estimates from Riding Mountain may be spuriously high due to the absence of modern analogues for pollen spectra deposited between 6000 and 3000 yr BP (Ritchie, 1983), but are ca. $3^{\circ} \mathrm{C}$ above present from 8500 to $6000 \mathrm{yr} \mathrm{BP}$, a more reasonable estimate of 6 ka growing season temperature is $1.5^{\circ}$ to $3^{\circ} \mathrm{C}$ above current values. At Lofty Lake, growing season precipitation is estimated to have been $50 \mathrm{~mm}$ below current values between 8000 and $6000 \mathrm{yr}$ BP. This suggests that the early to middle Holocene aridity registered in many previously discussed records was the result of longstanding above normal temperatures coupled with a Holocene low in growing season precipitation. Zoltai and Vitt (1990), in documenting the Holocene distribution of peatlands in the Canadian western interior, arrived at slightly different but comparable estimates, with mean July temperature only $0.5^{\circ} \mathrm{C}$ warmer than today but mean annual precipitation $65 \mathrm{~mm}$ lower than present at $6000 \mathrm{yr}$ BP.

\section{CONCLUSION}

The $6 \mathrm{ka}$ interval is a time of transition in the Canadian prairie provinces. Following late glacial-early Holocene vegetation migration and landscape stabilization, many prairie records outline an early Holocene episode of increased aridity between 9000 and 6000 yr BP. Although peak aridity had passed by $6000 \mathrm{yr}$ BP, the landscape remained influenced by this prolonged period of warm and dry climatic conditions (Fig. 8). In the mountains, glaciers were smaller than present, upper treeline was upslope of its current position, montane forests were subjected to more frequent fires than experienced at present, and grassland persisted 
on presently forested floors of the major river valleys. In the foothills, lower treeline moved upslope, grassland openings increased in size, and wetlands were reduced in size, compared to today.

On the plains, grassland extended northward into areas now occupied by parkland or boreal forest and eastward in Manitoba. In the core of the southern prairie grassland, many shallow lakes dried up and others were reduced to hypersaline playas. Only deep lakes or those with a reliable groundwater input remained perennial waterbodies. Reduced vegetation cover and high winds led to increased aeolian activity, compared to today.

The southern and northern limits of boreal forest were positioned further north than at present and, in the north, trees grew in areas now occupied by tundra. Fire frequency was higher in the boreal forest than at present, aiding the westward migration of jack pine.

As a time of transition, the $6 \mathrm{ka}$ interval falls between the driest postglacial period and the onset of climatic conditions

\section{a}



Non-analogue Vegetation similar to present. The onset of cooler and moister conditions, like the onset of postglacial warming (Ritchie and Harrison, 1993), is time-transgressive, occurring earlier (6000-5000 yr BP) in the west and later (4000-3000 yr BP) in the east. The upper limit of tree growth in the Rocky Mountains declined markedly between 6000 and $4000 \mathrm{yr}$ BP (Luckman and Kearney, 1986). Lower treeline receded downslope at 5500 yr BP in western Alberta (MacDonald, 1989) and, in central Alberta, lake infilling and freshening was widespread by 5000 yr BP (Schweger and Hickman, 1989). Increasingly moister conditions are evident in southern Saskatchewan between 5500 yr BP (Sauchyn and Sauchyn, 1991) and 4000 yr BP (Vance and Last, 1994), but are not apparent in southern Manitoba until about 3500 BP (Ritchie and Lichti-Federovich, 1968).

Although quantitative estimates of the climatic changes responsible for these vegetation and hydrologic changes are varied, all concur in suggesting that increased temperature was a distinguishing feature of 6 ka climate, with mean annual temperature between 0.5 and $1.5^{\circ} \mathrm{C}$ higher than

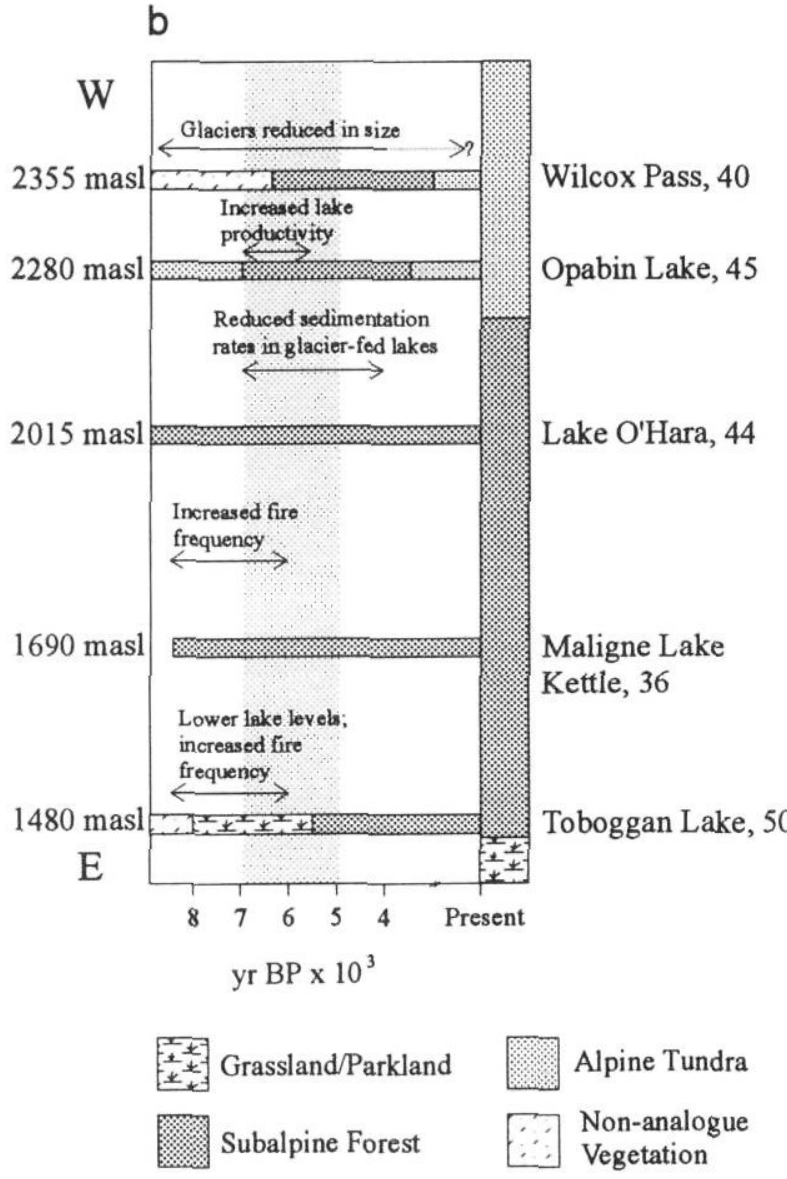

Diagramme synthèse de la paléoécologie des provinces des prairies le long d'un transect nord-sud (a) et d'un transect est-ouest en progression altitudinale (b) dans la région du piémont et des Rocheuses. L'intervalle de 6 ka (5000-7000 BP) est tramé. Tous les commentaires se rapportent à des conditions comparées à celles d'aujourd'hui. 
present, and summer temperature between 0.5 and $3.0^{\circ} \mathrm{C}$ above current values. Reduced precipitation, compared to today, is also indicated by these estimates (mean annual by $65 \mathrm{~mm}$ and growing season by $50 \mathrm{~mm}$ ).

Responses to $6 \mathrm{ka}$ climate outlined in prairie paleoecological records suggest that $6 \mathrm{ka}$ atmospheric circulation may have been characterized by frequent incursions of Pacific air masses into the western Canadian interior, driven by vigorous westerly flow. The zonal circulation pattern that prevailed through the 1930s (Dzerdzeevskii, 1969; Namias, 1983) may be the most appropriate historic analogue, with at least one significant difference. The minimal precipitation deficiencies experienced in the southern boreal forest in the 1930s (Chakravarti, 1976; Singh and Powell, 1986) are probably insufficient, even if experienced for several decades and accompanied by slightly warmer temperatures, to stimulate the widespread desiccation of shallow wetlands and northward movement of grassland and boreal forest ecozones outlined in $6 \mathrm{ka}$ proxy records. Persistence of Pacific air masses over the central area of the prairie provinces, produced by a northward shift of the westerly track compared to the 1930 s, is most likely required to produce the environmental changes outlined in this synthesis.

Although the effects of 6 ka climate are apparent in all ecozones, the clearest response to climate change is found at sensitive ecotonal sites, for example in the upper subalpine treeline or on the fringes of the grassland. Because these areas provide the best opportunity to obtain numerical estimates of climatic parameters for direct comparison with GCM output, ecotonal sites should be the focus of future research on the Holocene environmental history of the prairie provinces.

\section{ACKNOWLEDGEMENTS}

We thank $W$. Johnson for providing the map that formed the basis of Figures 1 and 3, G.M. MacDonald and M.A. Reasoner for permission to reproduce the Toboggan and Opabin Lakes data, K. Gajewski and H. Jetté for access to the Lofty Lake data, and E.C. Grimm for the Toboggan Lake and Riding Mountain data. This manuscript benefitted from comments by W.M. Last, R.G. Baker and an anonymous reviewer.

\section{REFERENCES}

Alley, N.F., 1972. The Quaternary History of Part of the Rocky Mountains Foothills, Plains and Western Porcupine Hills, Southwestern Alberta. Ph.D. dissertation, Department of Geography, University of Calgary.

Anderson, T.W., Mathewes, R.W. and Schweger, C.E., 1989. Holocene Climatic Trends in Canada with Special Reference to the Hypsithermal Interval, p. 520-528. In R.J. Fulton, ed., Quaternary Geology of Canada and Greenland. Geology of Canada No. 1. Geological Survey of Canada.

Atmospheric Environment Service, 1982. Canadian Climate Normals 19511980. Environment Canada, Ottawa.

Bacon, C.R., 1983. Eruptive History of Mount Mazama and Crater Lake Caldera, Cascade Range, U.S.A. Journal of Volcanology and Geotherma Research, 18: 57-115.
Barnosky, C.W., 1989. Postglacial Vegetation and Climate in the Northwestern Great Plains of Montana. Quaternary Research, 31: 57-73.

Barnosky, C.W., Grimm, E.C. and Wright Jr., H.E., 1987. Towards a Postglacial History of the Northern Great Plains: A Review of the Paleoecologic Problems. Annals of Carnegie Museum, 56: 259-273.

Bear, R.L., 1989. The Holocene Palaeoecology of Lorraine Lake, Jasper National Park, Alberta. M.Sc. dissertation, Department of Botany, University of Alberta.

Beaudoin, A.B., 1984. Holocene Environmental Change in the Sunwapta Pass Area, Jasper National Park. Ph.D. dissertation, Department of Geography, University of Western Ontario, London.

___ 1986. Using Picea/Pinus Ratios from the Wilcox Pass Core, Jasper National Park, Alberta, to Investigate Holocene Timberline Fluctuations. Géographie physique et Quaternaire, 40: 145-152.

__ 1992. Early Holocene Palaeoenvironmental Data Preserved in "NonTraditional" Sites. The 2nd Palliser Triangle Global Change Conference, Regina, Saskatchewan, Program with Abstracts.

__ 1993. A Compendium and Evaluation of Postglacial Pollen Records in Alberta. Canadian Journal of Archaeology, 17: 92-112.

Beaudoin, A.B. and King, R.H., 1990. Late Quaternary Vegetation History of Wilcox Pass, Jasper National Park, Alberta. Palaeogeography, Palaeoclimatology, Palaeoecology, 80: 129-144.

Bombin, E.R., 1982. Holocene Paleolimnology of Mary Gregg Lake, Foothills of the Canadian Rocky Mountains, Canada. M.Sc. dissertation. Department of Botany, University of Alberta, Edmonton, 147 p.

Bryan, R.B., Campbell, I.A. and Yair, A., 1987. Postglacial Geomorphic Development of the Dinosaur Provincial Park Badlands, Alberta. Canadian Journal of Earth Sciences, 24: 135-146.

Bryson, R.A., 1966. Air Masses, Streamlines, and the Boreal Forest. Geographical Bulletin, 8: 228-269.

Bujak, C.A., 1974. Recent Palynology of Goat Lake and Lost Lake, Waterton Lakes National Park. M.A. dissertation, Department of Geography, University of Calgary, $60 \mathrm{p}$.

Chakravarti, A.K., 1976. Precipitation Deficiency Patterns in the Canadian Prairies, 1921 to 1970. Prairie Forum, 1: 95-110.

Cvancara, A.M., Clayton, L., Bickley Jr., W.B., Jacob, A.F., Shay, C.T., Delorme, L.D. and Lammers, G.E., 1971. Paleolimnology of Late Quaternary Deposits: Siebold Site, North Dakota. Science, 171: 172-174.

Dredge, L.A. and Cowan, W.R., 1989a. Quaternary Geology of the Southwestern Canadian Shield, p. 214-234. In R.J. Fulton, ed., Quaternary Geology of Canada and Greenland. Geology of Canada No. 1, Geological Survey of Canada.

1989b. Lithostratigraphic Record on the Canadian Shield, p. 235249. In R.J. Fulton, ed., Quaternary Geology of Canada and Greenland. Geology of Canada No. 1, Geological Survey of Canada.

Dzerdzeevskii, B.L., 1969. Climatic Epochs in the Twentieth Century and Some Comments on the Analysis of Past Climates, p. 49-60. In H.E. Wright Jr. ed., Quaternary Geology and Climate. Volume 16 of the Proceedings of the VII Congress of the International Association for Quaternary Science, National Academy of Sciences, Washington, D. C.

Faegri, K., Kaland, P. and Krzywinski, K., 1989. Textbook of Pollen Analysis, $4^{\text {th }}$ Edition. John Wiley, Chichester, $328 \mathrm{p}$.

Forbes, J.R. and Hickman, H., 1981. Paleolimnology of Two Shallow Lakes in Central Alberta, Canada. Internationale Revue der gesamten Hydrobiologie, 66: 863-877.

Guliov, P., 1963. Paleoecology of Invertebrate Fauna from Post-glacial Sediment Near Earl Grey, Saskatchewan. M.A. thesis. Department of Geological Sciences, University of Saskatchewan, Saskatoon, 95 p.

Hickman, M., 1987. Paleolimnology of a Large Shallow Lake, Cooking Lake, Alberta, Canada. Archiv für Hydrobiologie, 111: 121-136.

Hickman, M. and Klarer, D.M., 1981. Paleolimnology of Lake Isle, Alberta, Canada (Including Sediment Chemistry, Pigments and Diatom Stratigraphy). Archiv für Hydrobiologie, 91: 490-508. 
Hickman, M. and Schweger, C.E., 1991. A Palaeoenvironmental Study of Fairfax Lake, a Small Lake Situated in the Rocky Mountain Foothills of West-central Alberta. Journal of Paleolimnology, 6: 1-15.

1993. Late Glacial-Early Holocene Paleosalinity in Alberta, Canada - Climate Implications. Journal of Paleolimnology, 8: 149-161.

Hickman, M., Schweger, C.E. and Habgood, T., 1984. Lake Wabamun, Alta.: A Paleoenvironmental Study. Canadian Journal of Botany, 62: 1438-1465.

Hickman, M., Schweger, C.E. and Klarer, D.M., 1990. Baptiste Lake, Alberta - A Late Holocene History of Changes in a Lake and its Catchment in the Southern Boreal Forest. Journal of Paleolimnology, 4: 253 . 267.

Hickman, M. and White, J.M., 1989. Late Quaternary Paleoenvironments of Spring Lake, Alberta, Canada. Journal of Paleolimnology, 2: 305-317.

Hills, L.V., Christensen, O.A., Fergusson, A., Driver, J.C. and Reeves, B.O.K., 1985. Postglacial Pollen and Paleoclimate in Southwestern Alberta and Southeastern Saskatchewan, p. 345-396. In C.R. Harington, ed., Climatic Change in Canada 5. Critical Periods in the Quaternary Climatic History of Northern North America. National Museum of Natural Sciences Project on Climatic Change in Canada During the Past 20,000 Years. Syllogeus No. 55.

Husband, B.C. and Hickman, M., 1985. Growth and Biomass Allocation of Ruppia occidentalis in Three Lakes, Differing in Salinity. Canadian Journal of Botany, 63: 2004-2014.

Janz, B. and Storr, D., 1977. The Climate of the Contiguous Mountain Parks. Project Report 30, prepared for Parks Canada. Atmospheric Environment Service, Department of Environment, 324 p.

Jetté, H., 1995. A Canadian Contribution to the Paleoclimate Model Intercomparison Project (PMIP). Géographie physique et Quaternaire. 49 (1) : 4-12.

Kearney, M.S., 1981. Late Quaternary Vegetational and Environmental History of Jasper National Park, Alberta. Ph.D. dissertation. Department of Geography, University of Western Ontario, London, 318 p

- 1982. Recent Seedling Establishment at Timberline in Jasper National Park, Alta. Canadian Journal of Botany, 60: 2283-2287.

Kearney, M.S. and Luckman, B.H., 1983. Postglacial Vegetational History of Tonquin Pass, British Columbia. Canadian Journal of Earth Sciences, 20: $776-786$.

1987. A Mid-Holocene Vegetational and Climatic Record from the Subalpine Zone of the Maligne Valley, Jasper National Park, Alberta (Canada). Palaeogeography, Palaeoclimatology, Palaeoecology, 59: 227 242

Kingston, M.S., 1982. An Evaluation of the Recommended Methods for Paleosol Investigations; A Case Study of a Holocene Paleosol, Calgary, Alberta. M.Sc. dissertation, Department of Geography, University of Western Ontario, London, $166 \mathrm{p}$.

Klassen, R.W., 1989. Quaternary Geology of the Southern Canadian Interior Plains, p. 138-173. In R.J. Fulton, ed., Quaternary Geology of Canada and Greenland. Geology of Canada No. 1. Geological Survey of Canada.

Kubiw, H., Hickman, M. and Vitt, D.H., 1989. The Development of Peatlands at Muskiki and Marguerite Lakes, Alberta. Canadian Journal of Botany. 67: 3534-3544.

Kuhry, P., Halsey, L.A., Bayley, S.E. and Vitt, D.H., 1992. Peatland Development in Relation to Holocene Climatic Change in Manitoba and Saskatchewan (Canada). Canadian Journal of Botany, 29: 1070-1090.

Kuhry, P., Nicholson, Gignac, L.D., Vitt, D.H. and Bayley, S.E., 1993. Development of Sphagnum-dominated Peatlands in Boreal Continental Canada. Canadian Journal of Botany, 71: 10-22.

Kupsch, W.O., 1960. Radiocarbon-dated Organic Sediment Near Herbert, Saskatchewan. American Journal of Science, 258: 282-292.

Last, W.M., 1990. Paleochemistry and Paleohydrology of Ceylon Lake, a Salt-Dominated Playa Basin in the Northern Great Plains, Canada. Journal of Paleolimnology, 4: 219-238.
1993. Rates of Sediment Deposition in a Hypersaline Lake in the Northern Great Plains, Western Canada. International Journal of Salt Research, 2: 47-58.

Last, W.M. and Sauchyn, D.J., 1993. Mineralogy and Lithostratigraphy of Harris Lake, Southwestern Saskatchewan, Canada. Journal of Paleolimnology, 9: 23-39.

Last, W.M. and Schweyen, T.H., 1985. Late Holocene History of Waldsea Lake, Saskatchewan, Canada. Quaternary Research, 24: 219-234.

Last, W. and Slezak, L.A., 1986. Paleohydrology, Sedimentology, and Geochemistry of Two Meromictic Saline Lakes in Southern Saskatchewan. Géographie physique et Quaternaire, 40: 5-15.

Last, W.M. and Teller, J.T., 1983. Holocene Climate and Hydrology of the Lake Manitoba Basin, p. 333-353. In J.T. Teller, and L. Clayton, eds., Glacial Lake Agassiz. Geological Association of Canada Special Paper No. 26.

Laycock, A.H., 1972. The Diversity of the Physical Landscape, p. 1-32. In P.J. Smith, ed., Studies in Canadian Geography - The Prairie Provinces. The University of Toronto Press.

Leonard, E.M., 1986. Use of Lacustrine Sedimentary Sequences as Indicators of Holocene Glacial History, Banff National Park, Alberta, Canada. Quaternary Research, 26: 218-231.

Lichti-Federovich, S., 1970. The Pollen Stratigraphy of a Dated Section of Late Pleistocene Lake Sediment Core from Central Alberta. Canadian Journal of Earth Sciences, 7: 938-945.

- 1972. Pollen Stratigraphy of a Sediment Core from Alpen Siding Lake, Alberta. Report of Activities, Part B. Geological Survey of Canada Paper, 72-1B: 113-115.

Longley, R.W., 1972. The Climate of the Prairie Provinces. Climatological Studies No. 13. Environment Canada, Atmospheric Environment Service.

Lowden, J.A. and Blake Jr., W., 1980. Geological Survey of Canada, Radiocarbon Dates XIX. Geological Survey of Canada Paper 79-7.

Luckman, B.H., 1988. 8000 Year Old Wood from the Athabasca Glacier, Alberta. Canadian Journal of Earth Sciences, 25: 148-151.

- 1990. Mountain Areas and Global Change: A View from the Canadian Rockies. Mountain Research and Development, 10: 183-195.

Luckman, B.H., Holdsworth, G. and Osborn, G.D., 1993. Neoglacial Glacial Fluctuations on the Canadian Rockies. Quaternary Research, 39: 144153.

Luckman, B.H. and Kearney, M.S., 1986. Reconstruction of Holocene Changes in Alpine Vegetation and Climate in the Maligne Range, Jasper National Park, Alberta. Quaternary Research, 26: 244-261.

Luckman, B.H. and Osborn, G.D., 1979. Holocene Glacier Fluctuations in the Middle Canadian Rocky Mountains. Quaternary Research, 11: 52 77.

MacDonald, G.M., 1982. Late Quaternary Paleoenvironments of the Morley Flats and Kananaskis Valley of Southwestern Alberta. Canadian Journal of Earth Sciences, 19: 23-35.

1984. Postglacial Plant Migration and Vegetation Development in the Western Canadian Boreal Forest. Ph.D. dissertation. Department of Botany, University of Toronto.

1987. Postglacial Development of the Subalpine-Boreal Transition Forest of Western Canada. Journal of Ecology, 75: 303-320.

1989. Postglacial Palaeoecology of the Subalpine Forest-Grassland Ecotone of Southwestern Alberta: New Insights on Vegetation and Climate Change in the Canadian Rocky Mountains and Adjacent Foothills. Palaeogeography, Palaeoclimatology, Palaeoecology, 73: 155-173.

MacDonald, G.M., Beukens, R.P. and Kieser, W.E., 1991. Radiocarbon Dating of Limnic Sediments: A Comparative Analysis and Discussion. Ecology, 72: 1150-1155.

MacDonald, G.M., Beukens, R.P. Kieser, W.E. and Vitt, D.H., 1987. Comparative Radiocarbon Dating of Terrestrial Plant Macrofossils and Aquatic Moss from the "Ice-Free Corridor" of Western Canada. Geology, 15: 837840. 
MacDonald, G.M. and Cwynar, L.C., 1985. A Fossil Pollen Based Reconstruction of the Late Quaternary History of Lodgepole Pine (Pinus contorta ssp. latifolia) in the Western Interior of Canada. Canadian Journal of Forest Research, 15: 1039-1044.

MacDonald, G.M. and Ritchie, J.C., 1986. Modern pollen spectra from the western interior of Canada and the interpretation of late Quaternary vegetation development. New Phytologist, 103: 245-268.

Mathewes, R.W. and Westgate, J.A. 1980. Bridge River Tephra: Revised Distribution and Significance for Detecting Old Carbon Errors in Radiocarbon Dates of Limnic Sediment in Southern British Columbia. Canadian Journal of Earth Sciences, 17: 1454-1461.

Matthews Jr., J.V., 1980. Paleoecology of John Klondike Bog, Fisherman Lake Region, Southwest District of Mackenzie. Geological Survey of Canada Paper, 80-22. $12 \mathrm{p}$.

McAndrews, J.H., 1982. Holocene Environment of a Fossil Bison from Kenora, Ontario. Ontario Archaeology, 37: 41-51.

McAndrews, J.H., Stewart Jr., R.E. and Bright, R.C., 1967. Paleoecology of a Prairie Pothole: A Preliminary Report, p. 101-113. In L. Clayton and T.F. Freers, eds., Glacial Geology of the Missouri Couteau and Adjacent Areas. Miscellaneous Series 30. North Dakota Geological Survey, Grand Forks.

Moore, P.D., Webb, J.A. and Collinson, M.E., 1991. Pollen Analysis, $2^{\text {nd }}$ Edition. Blackwell , Oxford, $216 \mathrm{p}$.

Mott, R.J., 1973. Palynological Studies in Central Saskatchewan. Pollen Stratigraphy from Lake Sediment Sequences. Geological Survey of Canada Paper, 72-49.

1978. Populus in late-Pleistocene pollen spectra. Canadian Journal of Botany, 56: 1021-1031.

Mott, R.J. and Christiansen, E.A., 1981. Palynological Study of Slough Sediments from Central Saskatchewan. In Current Research B. Geological Survey of Canada Paper, 81-1B: 133-136.

Mott, R.J. and Jackson Jr., L.E., 1982. An 18,000 Year Palynological Record from the Southern Alberta Segment of the Classical Wisconsinan "Ice Free Corridor". Canadian Journal of Earth Sciences, 19: 504-513.

Namias, J., 1983. Some Causes of United States Drought. Journal of Climate and Applied Meteorology, 22: 30-39.

North, M.A., 1992. Preliminary Palynological Record from Elkwater Lake, Cypress Hills, Alberta, Covering the Last 5,000 years. The $2^{\text {ro }}$ Palliser Triangle Global Change Conference, Program with Abstracts.

Nichols, H., 1967. The Post-glacial History of Vegetation and Climate at Ennadai Lake, Keewatin, and Lynn Lake, Manitoba, Canada. Eiszeitalter und Gegenwart, 18: 176-197.

- 1969. The Late Quaternary History of Vegetation and Climate at Porcupine Mountain and Clearwater Bog. Arctic and Alpine Research. 1: $155-167$.

Nicholson, B. and Vitt, D.H., 1990. The Paleoecology of a Peatland Complex in Continental Western Canada. Canadian Journal of Botany, 68: 121-138.

Pennock, D.J. and Vreeken, W.J., 1986, Influence of Site Topography on Paleosol Formation in the Highwood River Basin, Southern Alberta. Canadian Journal of Soil Science, 66: 673-688.

Reasoner, M.A. and Hickman, M., 1989. Late Quaternary Environmental Change in the Lake O'Hara Region, Yoho National Park, British Columbia. Palaeogeography, Palaeoclimatology, Palaeoecology, 72: 291-316.

Reasoner, M.A., Osborn, G. and Rutter, N.W., 1993. The Age of the Crowfoot Moraine System in the Canadian Rocky Mountains: A Possible Younger Dryas Time Equivalent Glacial Event. CANQUA '93 Program with Abstracts and Field Guide, p. A37.

Reeves, B.O.K. and Dormaar, J., 1972. A Partial Holocene Pedological and Archaeological Record from the Southern Alberta Rocky Mountains. Arctic and Alpine Research, 4: 325-336.

Ritchie, J.C., 1964. Contributions to the Holocene Paleoecology of WestCentral Canada. I. The Riding Mountain Area. Canadian Journal of Botany, 42: 181-197.
1966. Aspects of the Late-Pleistocene History of the Canadian Flora, p. 66-80. In R.L. Taylor, and R.A. Ludwig, eds., The Evolution of Canada's Flora. University of Toronto Press.

1969. Absolute Pollen Frequency and Carbon-14 Age of a Section of Holocene Lake Sediment from the Riding Mountain Area of Manitoba. Canadian Journal of Botany, 47: 1345-1349.

1976. The Late-Quaternary Vegetational History of the Western Interior of Canada. Canadian Journal of Botany, 54: 1793-1818.

1983. The Paleoecology of the Central and Northern Parts of the Glacial Lake Agassiz Basin, p. 157-170. In J.T. Teller, and L. Clayton, ed., Glacial Lake Agassiz. Geological Association of Canada Special Paper No. 26.

1985. Quaternary Pollen Records from the Western Interior and the Arctic of Canada, p. 327-352. In V.M. Bryant Jr. and R.G. Holloway, eds., Pollen Records of Late-Quaternary North American Sediments. AASP Foundation, Texas.

1987. Postglacial Vegetation of Canada. Cambridge University Press, $178 \mathrm{p}$.

1989. History of the Boreal Forest in Canada, p. 508-512. In R.J Fulton, ed., Quaternary Geology of Canada and Greenland. Geology of Canada No. 1. Geological Survey of Canada.

Ritchie, J.C. and de Vries, B., 1964. Contributions to the Holocene Paleoecology of West Central Canada. II. A Late-glacial Deposit from the Missouri Couteau. Canadian Journal of Botany, 42: 677-692.

Ritchie, J.C. and Hadden, K.A., 1975. Pollen Stratigraphy of Holocene Sediments from the Grand Rapids Area, Manitoba. Review of Palaeobotany and Palynology, 19: 193-202.

Ritchie, J.C. and Harrison, S.P., 1993. Vegetation, Lake Levels, and Climate in Western Canada during the Holocene, p. 401-414. In H.E. Wright, Jr., J.E. Kutzbach, T. Webb III, W.F. Ruddiman, F.A. StreetPerrott and P.J. Bartlein, eds., Global Climates Since the Last Glacial Maximum. University of Minnesota Press, Minneapolis

Ritchie, J.C. and Lichti-Federovich, S., 1968. Holocene Pollen Assemblages from the Tiger Hills, Manitoba. Canadian Journal of Earth Sciences, 5: 873-880.

Rowe, J.S., 1972. Forest Regions of Canada. Canadian Forestry Service, Publication No. 1300. Department of Environment, 172 p.

Sarna-Wojcicki, A.M., Champion, D.E. and Davis, J.O., 1983. Holocene Volcanism in the Conterminous United States and the Role of Silicic Volcanic Ash Layers in Correlation of Latest-Pleistocene and Holocene Deposits, p. 52-77. In H.E. Wright Jr., ed., Late Quaternary Environments of the United States Volume 2. The Holocene. University of Minnesota Press, Minneapolis.

Sauchyn, M.A. and Sauchyn, D.J., 1991. A Continuous Record of Holocene Pollen from Harris Lake, Southwestern Saskatchewan, Canada Palaeogeography, Palaeoclimatology, Palaeoecology, 88: 13-23.

Schweger, C.E. and Hickman, M., 1989. Holocene Paleohydrology, Central Alberta: Testing the General-Circulation-Model Climate Simulations. Canadian Journal of Earth Sciences, 26: 1826-1833.

Singh, T. and Powell, J.M., 1986. Climatic Variation and Trends in the Boreal Forest Region of Western Canada. Climatic Change, 8: 267 . 278 .

Stuiver, M. and Becker, B., 1993. High-Precision Decadal Calibration of the Radiocarbon Time Scale, AD 1950-6000 BP. Radiocarbon, 35: 35-65.

Teller, J.T. and Last, W.M., 1990. Paleohydrological Indicators in Playas in Salt Lakes, With Examples from Canada, Australia, and Africa Palaeogeography, Palaeoclimatology, Palaeoecology, 76: 215-240.

Vance, R.E., 1986a. Pollen Stratigraphy of Eaglenest Lake, Northeastern Alberta. Canadian Journal of Earth Sciences, 23: 11-20.

1986b. Aspects of the Postglacial Climate of Alberta: Calibration of the Pollen Record. Géographie physique et Quaternaire, 40: 153-160.

- 1991. A Paleobotanical Study of Holocene Drought Frequency in Southern Alberta. Ph.D. dissertation. Department of Biological Sciences, Simon Fraser University, Burnaby, $180 \mathrm{p}$. 
Vance, R.E., Clague, J.J. and Mathewes, R.W., 1993. Holocene Paleohydrology of a Hypersaline Lake in Southeastern Alberta. Journal of Paleolimnology, 8: 103-120.

Vance, R.E., Emerson, D. and Habgood, T., 1983. A Mid-Holocene Record of Vegetative Change in Central Alberta. Canadian Journal of Earth Sciences, 20: 364-376.

Vance, R.E. and Last, W., 1994. Paleolimnology and Global Change on the Canadian Prairies. In Current Research, 1994-B: 49-58. Geological Survey of Canada, Ottawa.

Vance, R.E. Mathewes, R.W. and Clague, J.J., 1992. 7000 Year Record of Lake-Level Change on the Northern Great Plains: A High-Resolution Proxy of Past Climate. Geology, 20: 879-882.

Waters, P.L. and Rutter, N.W., 1984. Utilizing Paleosols and Volcanic Ash in Correlating Holocene Deposits in Southern Alberta, p. 203-223. In W.C. Mahaney, ed., Correlation of Quaternary Chronologies. GeoBooks, Norwich.

White, J.M. and Mathewes, R.W., 1982. Holocene Vegetation and Climatic Change in the Peace River District, Canada. Canadian Journal of Earth Sciences, 19: 555-570.
1986. Postglacial Vegetation and Climatic Change in the Upper Peace River District, Alberta. Canadian Journal of Botany, 64: 23052318

White, J.M., Mathewes, R.W. and Mathews, W.H., 1985. Late Pleistocene Chronology and Environment of the "Ice-Free Corridor" of Northwestern Alberta. Quaternary Research, 24: 173-186.

White, J.M. and Osborn, G., 1992. Evidence for a Mazama-like Tephra Deposited ca. 10000 BP at Copper Lake, Banff National Park, Alberta. Canadian Journal of Earth Sciences, 29: 52-62.

Wilson, M.A., 1984. Postglacial Climatic and Vegetation History of the La Ronge Area, Northern Saskatchewan. SRC Publication No. R-743-2-E84. Saskatchewan Research Council, Saskatoon, 90 p.

Wilson, M.C., 1983. Once Upon A River: Archaeology and Geology of the Bow River Valley at Calgary, Alberta, Canada. National Museum of Man Mercury Series. Archaeological Survey of Canada, Paper No. 114, Ottawa. 464 p.

Zoltai, S.C., 1989. Late Quaternary Volcanic Ash in the Peatlands of Central Alberta. Canadian Journal of Earth Sciences, 26: 207-214.

Zoltai, S.C. and Vitt, D.H., 1990. Holocene Climatic Change and the Distribution of Peatlands in Western Interior Canada. Quaternary Research, 33: $231-240$. 